\title{
Oral mucosal changes induced by anticancer targeted therapies and immune checkpoint inhibitors
}

\author{
Emmanuelle Vigarios $^{1,2}$ • Joel B. Epstein ${ }^{3,4}$ - Vincent Sibaud ${ }^{1,5}$
}

Received: 21 September 2016 / Accepted: 6 February 2017 /Published online: 22 February 2017

(C) Springer-Verlag Berlin Heidelberg 2017

\begin{abstract}
Development of biological targeted therapies and immune checkpoint inhibitors has redefined the treatment for many cancers; however, the increasing use of new protocols has led to physicians observing a new spectrum of toxicities. To date, oral adverse events induced by these new anticancer therapies have been mainly reported using nonspecific terminology ("stomatitis," "mucosal inflammation," "mucositis") and remain poorly characterized, with the exception of mammalian target of rapamycin (mTOR) inhibitor-associated stomatitis. Oral toxicities of targeted therapies often display very characteristic features which clearly differ from classic oral injuries observed with cytotoxic chemotherapy and/or radiotherapy. In addition, they frequently affect more than $20 \%$ of treated patients and can lead to a significant morbidity or permanent treatment discontinuation. Oral mucosal toxicities described in this review include mTOR inhibitor-associated stomatitis (mIAS); stomatitis, benign migratory glossitis, and osteonecrosis of the jaw associated with multi-targeted kinase
\end{abstract}

Emmanuelle Vigarios

vigarios.emmanuelle@ iuct-oncopole.fr

1 Oral Medicine Department, Institut Claudius Regaud, Institut Universitaire du cancer Toulouse-Oncopole, 1 avenue Irène Joliot-Curie, 31059 Toulouse Cedex, France

2 UFR d'Odontologie 1 chemin des Maraîchers 31062, Toulouse Cedex 9, France

3 Samuel Oschin Comprehensive Cancer Institute, Cedars-Sinai Health System, Los Angeles, CA, USA

4 Otolaryngology and Head and Neck Surgery, City of Hope National Medical Center, Duarte, CA, USA

5 Oncodermatology Department, Institut Claudius Regaud, Institut Universitaire du cancer Toulouse-Oncopole, Toulouse, France inhibitors of the VEGF and PDGF receptors; mucositis induced by EGFR inhibitors (in monotherapy or in combination with head and neck radiotherapy and/or chemotherapy); hyperkeratotic lesions with BRAF inhibitors; pigmentary changes and lichenoid reactions secondary to imatinib; and more recent data on the "Osler-Weber-Rendu-like syndrome" described with the antibody-drug conjugate, TDM-1. Finally, we provide, to our knowledge, the first available structured data on oral toxicities induced by the new recently FDA- and EMA-approved monoclonal antibodies targeting PD-1. Clinical management of these targeted therapy-related oral changes is also discussed.

Keywords Mucosal changes · Oral cavity · Mucositis · Stomatitis $\cdot$ Mucosal sensitivity $\cdot$ Dysgeusia $\cdot$ Xerostomia . Lichenoid reaction $\cdot$ Hyperkeratotic lesion $\cdot$ Oral squamous cell carcinoma $\cdot$ Benign migratory glossitis .

Hyperpigmentation · Angiogenesis inhibitors · EGFR inhibitors · BRAF inhibitors $\cdot \mathrm{mTOR}$ inhibitors $\cdot \mathrm{BCR}-\mathrm{ABL}$ inhibitor · Cancer · Targeted therapies $\cdot$ Immune checkpoint inhibitors $\cdot$ Immunotherapy $\cdot$ Oral adverse events ·

Osteonecrosis of jaw $\cdot$ mIAS $\cdot$ Telangiectasias $\cdot$ Anti-PD-1

\section{Introduction}

Substantial progress in our understanding of the mechanism of oncogenesis has led to the emergence of numerous targeted anticancer therapies in the last decade [1-4]. Their therapeutic effects result mostly from the inhibition of specific molecular receptors and intracellular signaling pathways involved in tumor progression. Immune checkpoint inhibitors are also emerging as promising anticancer agents for a wide range of cancers (e.g., metastatic melanoma, advanced or refractory nonsmall cell lung cancer, renal cell cancer, Hodgkin lymphoma) by enhancing immune responses against malignant cells 
[5-9]. Their use is expected to increase exponentially in the future as their approval is extended to different tumor types $[10,11]$. Both targeted agents and immunotherapies now represent a major part of the oncologists' therapeutic arsenal and have redefined the treatment principles for many cancers.

Cutaneous toxicities are among the most frequently observed adverse events associated with the majority of targeted therapies. These toxicities are now well characterized, both in terms of their prevalence and in their multiple clinical manifestations [12-18]. Cutaneous toxicities also represent the most prevalent immune-related adverse events (IRae) associated with anticancer immunotherapies. The mechanism of action of immune checkpoint inhibitors involves triggering cytotoxic T-cell activation and induces a specific toxicity profile that is primarily of immunologic origin $[5,19,20]$.

Oral changes induced by targeted therapies are less well described and have been only sporadically characterized mainly reported using nonspecific terminology ("stomatitis," "mucositis"), except for mammalian target of rapamycin (mTOR) inhibitor-associated stomatitis (mIAS). However, oral toxicities of targeted therapies (Table 1) are not uncommon in clinical practice and frequently display very characteristic features [21-32] which differ significantly from those observed with chemotherapeutic agents [21, 23, 25, 26, 33].

Similarly, oral changes induced by immune checkpoint inhibitors have received limited attention to date in clinical trials [6-9, 20, 34-37], even though a spectrum of associated oral adverse events has recently emerged [20, 37, 38].

The purpose of our review is to describe the main oral mucosal changes observed with targeted therapies and immune checkpoint inhibitors. These oral toxicities clearly differ from classic oral injuries observed with chemotherapy and/or radiation therapy but might similarly impair patients' quality of life and might require dose modification or discontinuation of the treatment.

\section{Mammalian target of rapamycin (mTOR) inhibitors (Table 1)}

\section{mTOR inhibitor-associated stomatitis (mIAS)}

Incidence mIAS or aphthous-like stomatitis is a frequent and well-characterized oral toxicity in cancer patients treated with mTOR inhibitor therapy (everolimus, temsirolimus, deferolimus) [22, 27, 28, 32, 39]. The lesions are very similar to those initially described in transplant patients treated with sirolimus [32, 40]. mIAS is considered as a class effect [22], for which meta-analyses indicate the overall incidence of any grade and high grade $(\geq 3)$ (following NCI-CTCae) ranges from 33.5 to $52.9 \%$ and from 4.1 to $5.4 \%$, respectively, regardless of the type of mTOR inhibitor therapy [22, 39].

Overall, mIAS represents the most prevalent adverse event associated with this therapy and is the most frequent dose- limiting toxicity $[22,39]$. It is also the third most frequent severe adverse event associated with mTOR inhibitors (everolimus, temsirolimus) $[12,22,27,29,39]$ that can lead to dose modifications $[22,32,39,41]$ in about $5 \%$ of treated patients [22]. In addition, mIAS accounts for more than $10 \%$ of reasons for treatment discontinuation, reported to affect $2 \%$ of treated patients [22, 42].

Finally, it is important to note that the incidence of mIAS reported in pivotal studies has shown a tendency to decrease over time, potentially due to prevention and earlier management, as well as patient education.

\section{Comparison between everolimus and temsirolimus} Everolimus-induced mIAS represents the most common adverse event reported with this drug [43-48]. The incidence of mIAS of any grade associated with everolimus ranges from 24 to $64 \%$, according to the main pivotal studies [7, 43, 45-48] (Table 2). This incidence appears higher than that of all-grade mIAS induced by temsirolimus, which ranges from 14 to $40 \%$ of treated patients [49-52] (Table 2). Moreover, indirect comparisons between temsirolimus and everolimus reveal that the incidence of high-grade ( $\geq 3)$ mIAS with temsirolimus is less than 7\% [49-52] and slightly lower than with everolimus [7, 43, 45-48] (Table 2).

mTOR inhibitors in combination with endocrine agents In patients treated for breast cancer with the combination of everolimus and exemestane, mIAS represents the most common severe adverse event leading to dose reduction or interruption [42] and is the second most frequent cause of treatment discontinuation $[101,102]$. In the BOLERO-2 trial, the incidence of all-grade stomatitis was $67 \%$ (with $33 \%$ grade $\geq 2$ and $8 \%$ with grade 3 toxicity) in patients treated with everolimus (10 mg per day) plus exemestane (25 mg per day) for metastatic breast cancer [102]. In summary, this therapeutic combination significantly increases the incidence of all-grade mIAS $[44,101,102]$ compared to everolimus monotherapy.

Clinical presentation mIAS is now a well-described clinical toxicity which mostly occurs within the first cycle of treatment $[22,29,41]$, with a median time to onset of 10 days following the initiation of the treatment $[27,32,39]$. In the BOLERO-2 trial, the median time to grade $\geq 2$ onset was 2 weeks [102]. In addition, a recent meta-analysis conducted on phase 3 trials of everolimus (alone or in combination) as a treatment for different forms of solid cancers and tuberous sclerosis complex showed that a second flare occurred in about $40 \%$ of treated patients [42]. Nonetheless, both the rate of occurrence and degree of severity of mIAS generally decrease during the subsequent cycles of treatment [22].

mIAS is characterized by single or multiple, painful, and well-circumscribed round/ovoid superficial ulcers. The lesions generally measure a few millimeters in diameter and 


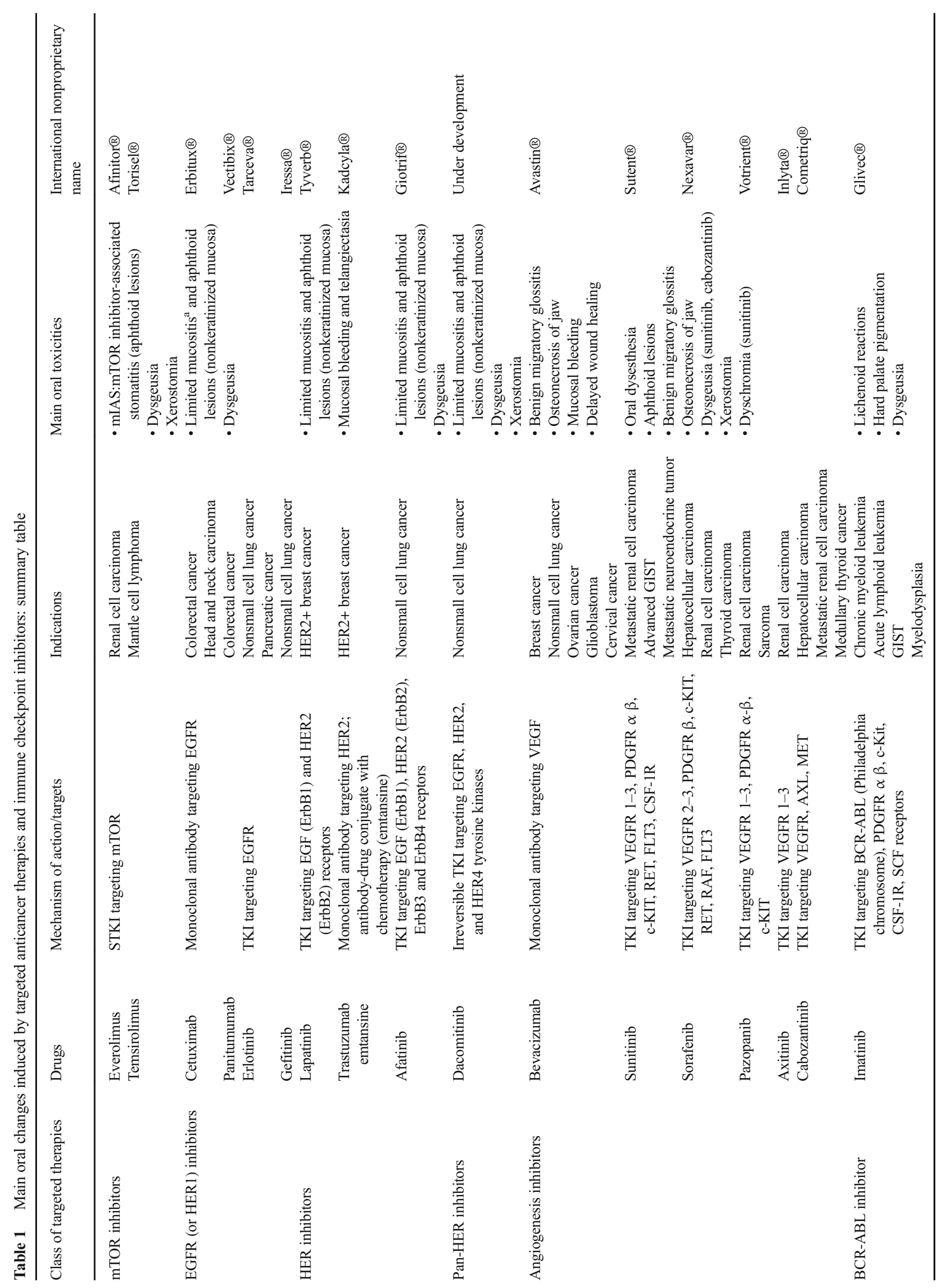




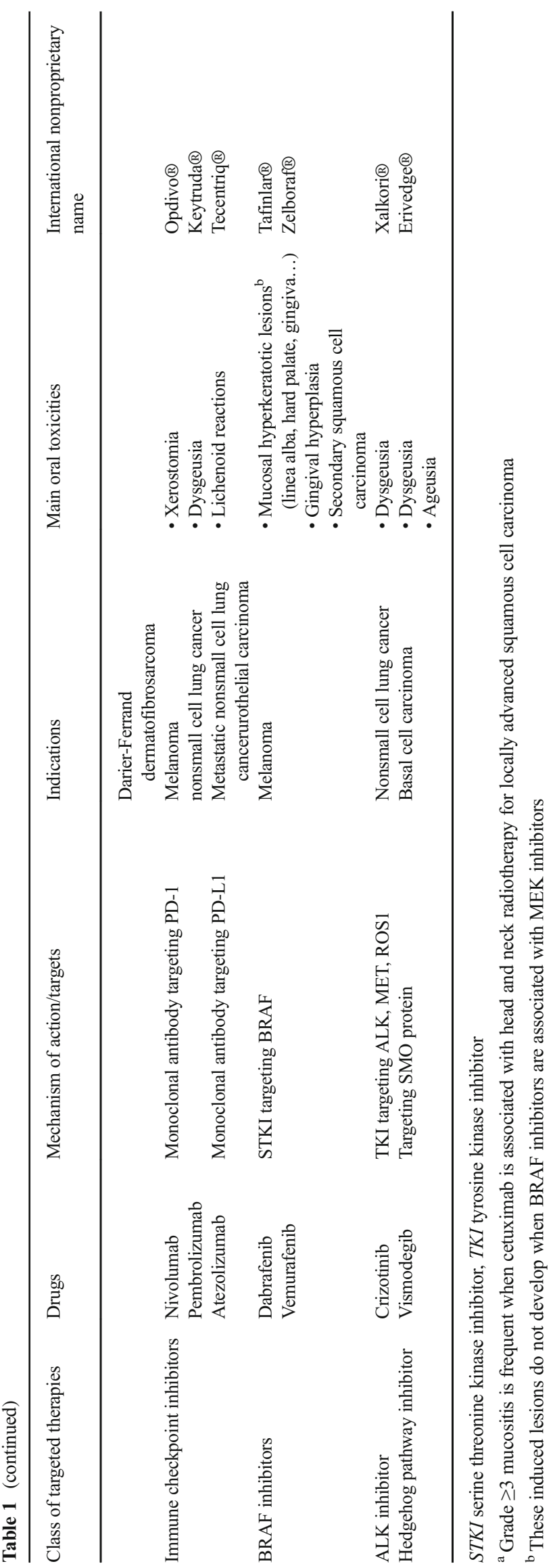

display a central gray area that is surrounded by an erythematous halo, mimicking recurrent aphthous stomatitis or herpetic lesions [22, 27, 32, 39, 42] (Fig. 1a, b). Major lesions can nonetheless sometimes be observed (Fig. 1c). mIAS mainly develops on the nonkeratinized mucosa (buccal mucosa, soft palate, ventral side and lateral borders of the tongue, or floor of the mouth) [22, 27, 32, 39].

These clinical features clearly differ from cytotoxic chemotherapy-induced mucositis, in which lesions are often more diffuse, larger, poorly circumscribed, and covered with a pseudomembrane consisting of fibrin, altered leucocytes, and epithelial debris (Fig. 2) [21, 103-105]. Gastrointestinal involvement is also frequently observed in mucositis associated with chemotherapy, whereas mIAS typically spares other mucosae $[27,28,32,39,42]$.

Management mIAS is a significant complication that can negatively impair adherence to the cancer treatment and affect the patient's quality of life. Therefore, prophylactic treatment and early recognition of this toxicity are fundamental.

\section{Prevention}

Early management consists of the promotion of good oral hygiene. Firstly, pretherapeutic oral screening is recommended in order to identify dental or periodontal disease outbreaks and ensure proper treatment. Oral examination is also necessary to eliminate potential sources of trauma (ill-fitting dentures, defective restorations, broken teeth, dental calculus, etc.) and detect preexisting mucosal disease [106]. Good oral health also relies on basic oral care interventions [33, 106-110] (Table 3).

In a recent phase 2 prevention trial (SWISH trial), Rugo et al. [111] reported on the prophylactic use of $10 \mathrm{~mL}$ of alcohol-free dexamethasone $(0.5 \mathrm{mg} / 5 \mathrm{~mL}$, four times daily for 8 weeks) mouthwash to prevent mIAS in patients receiving everolimus $10 \mathrm{mg} /$ exemestane $25 \mathrm{mg}$ for HR+, HER2- advanced or metastatic breast cancer. The incidence of all-grade mIAS in this group was $21.2 \%$, with $2.4 \%$ developing grade $\geq 2$ mIAS, and no patients developing grade 3 . Indirect comparison with the BOLERO-2 trial clearly indicates that prophylaxis with dexamethasone mouthwash significantly reduces the incidence or prevents the occurrence of all grades of mIAS, especially grade $\geq 2$ mIAS.

\section{Treatment}

In general, no intervention is required for grade 1 mIAS, except for maintaining a good standard of oral hygiene. Topical steroids should be considered as the first line of treatment for grade 2 mIAS [22, 32, 33, 39, 112]. Topical steroid mouthrinse (e.g., 


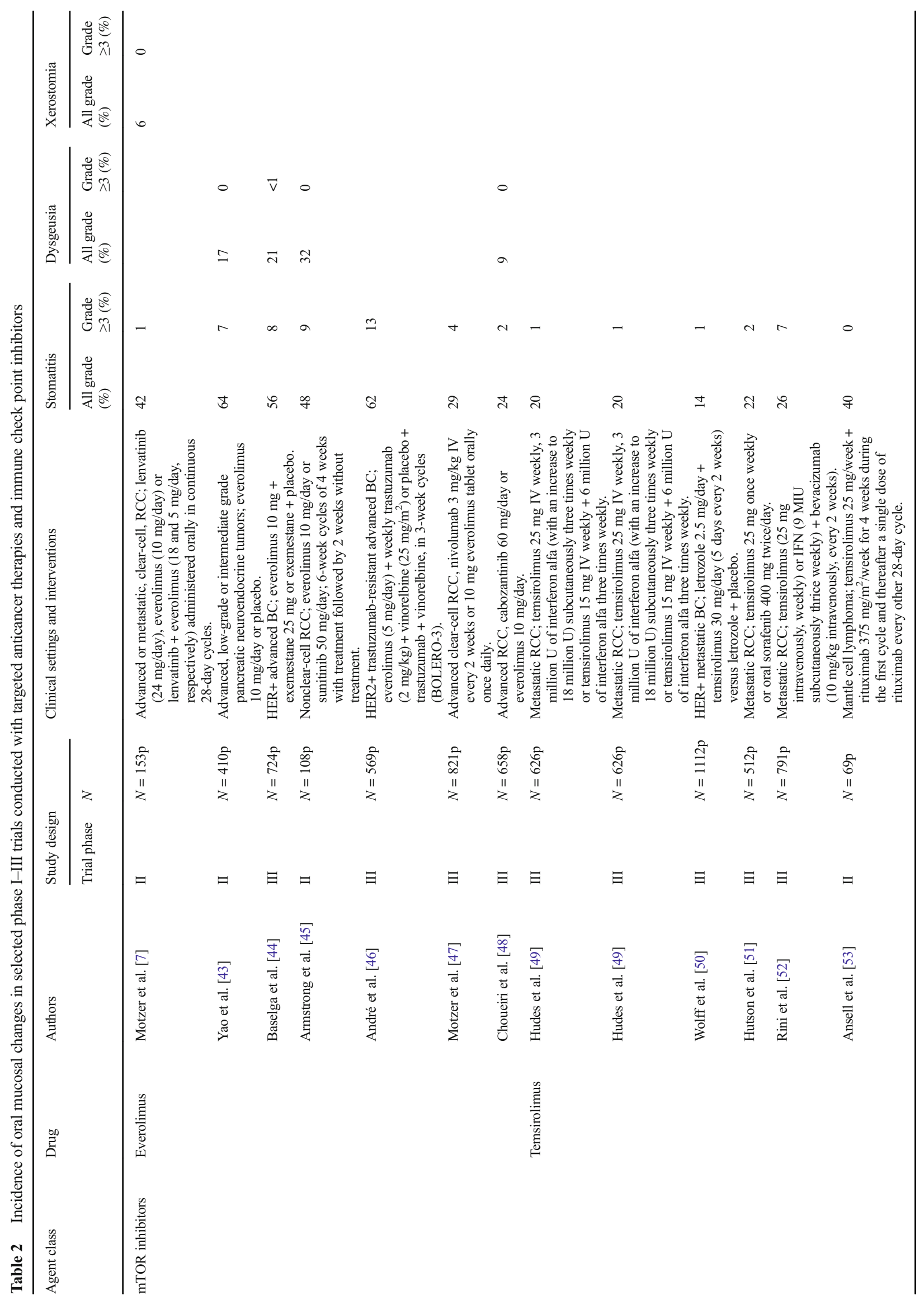




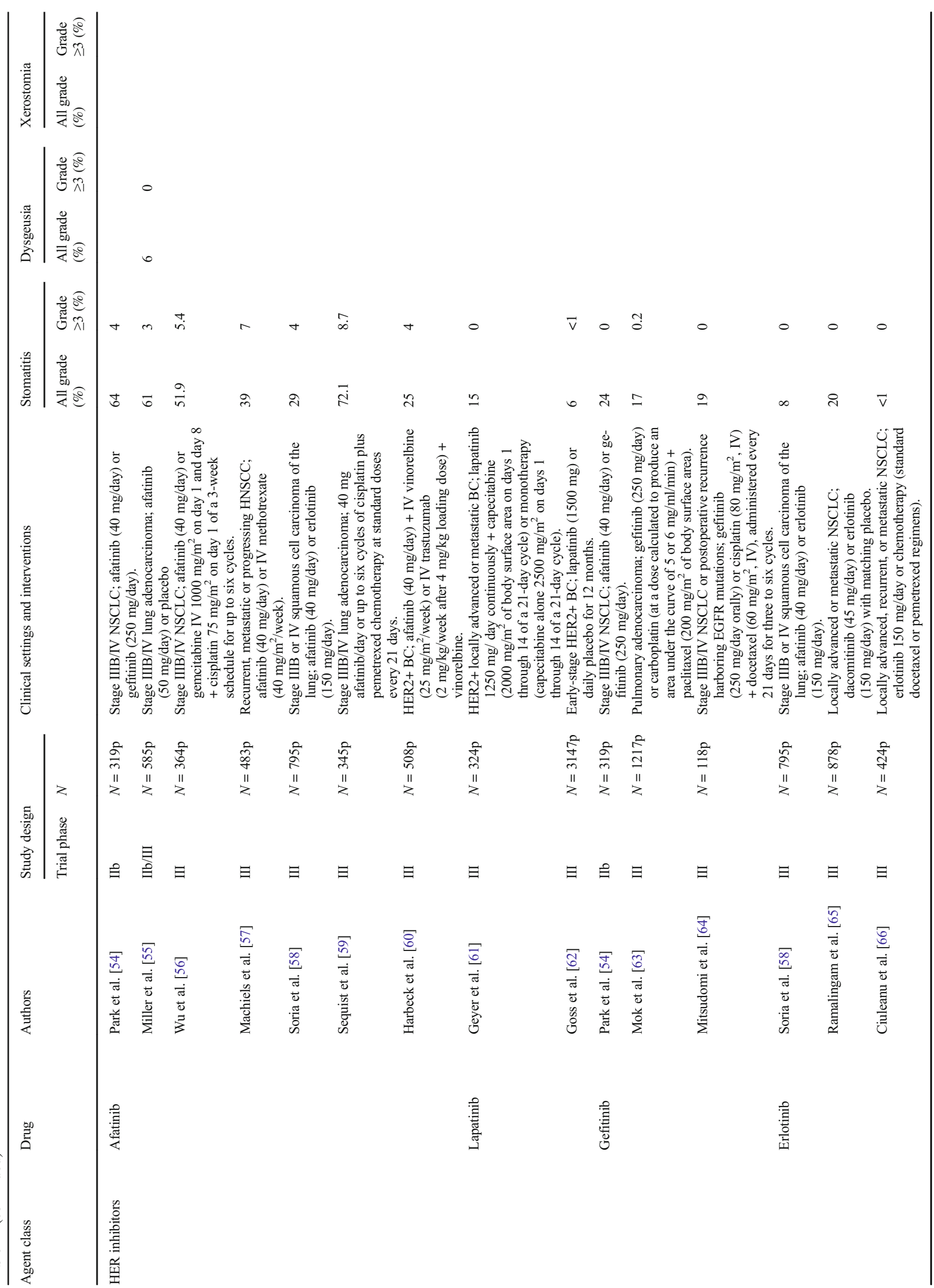




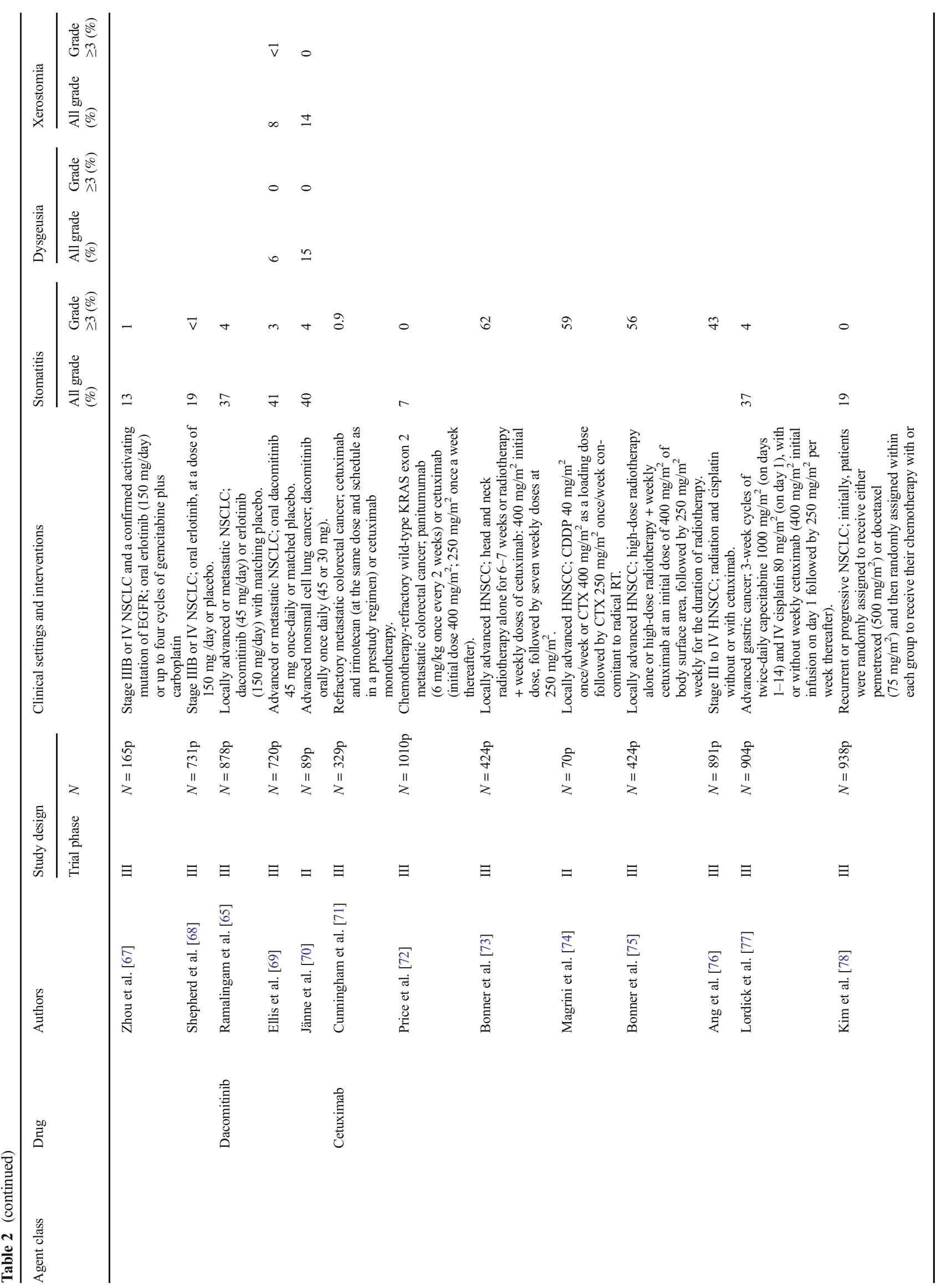




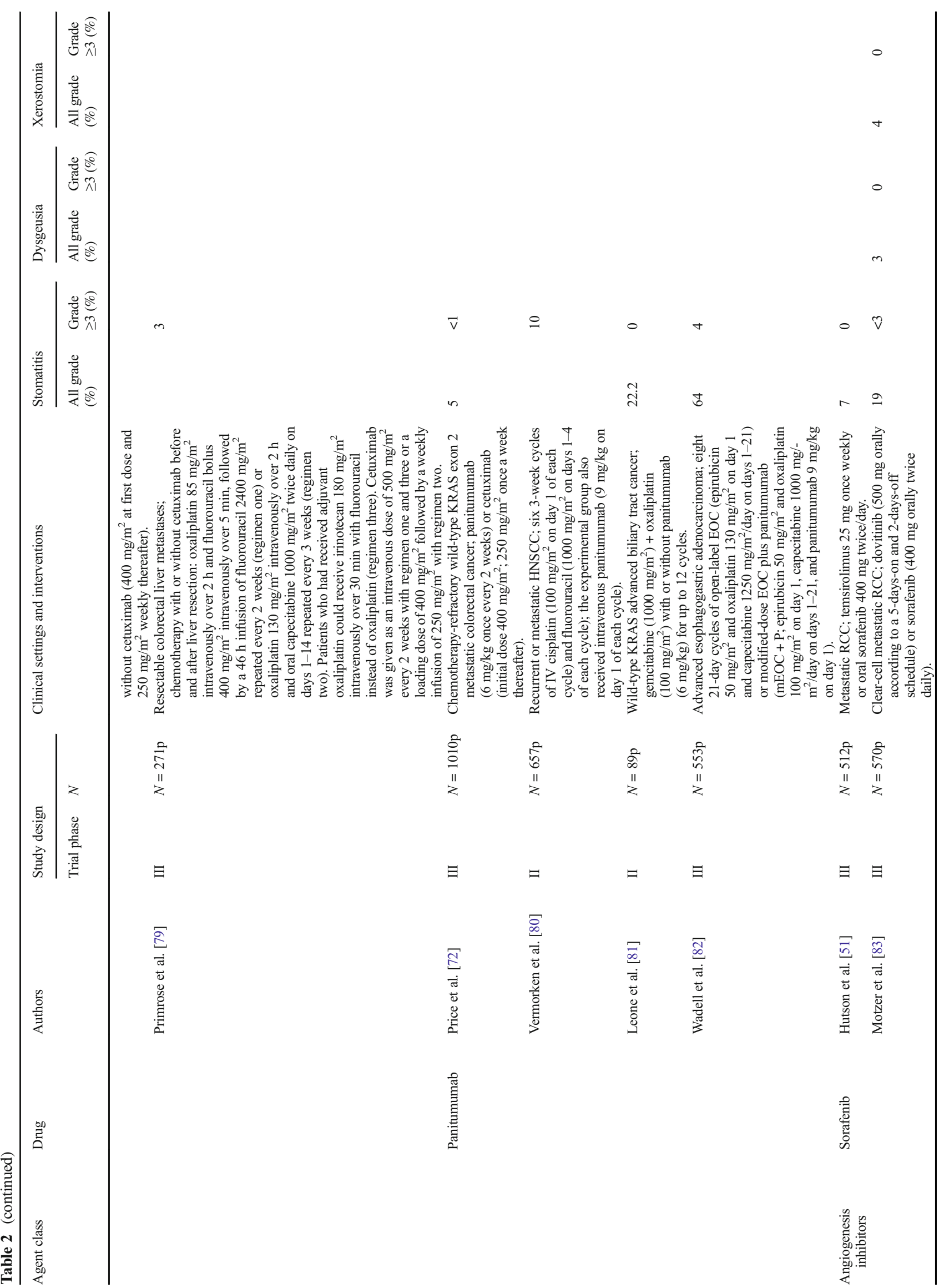




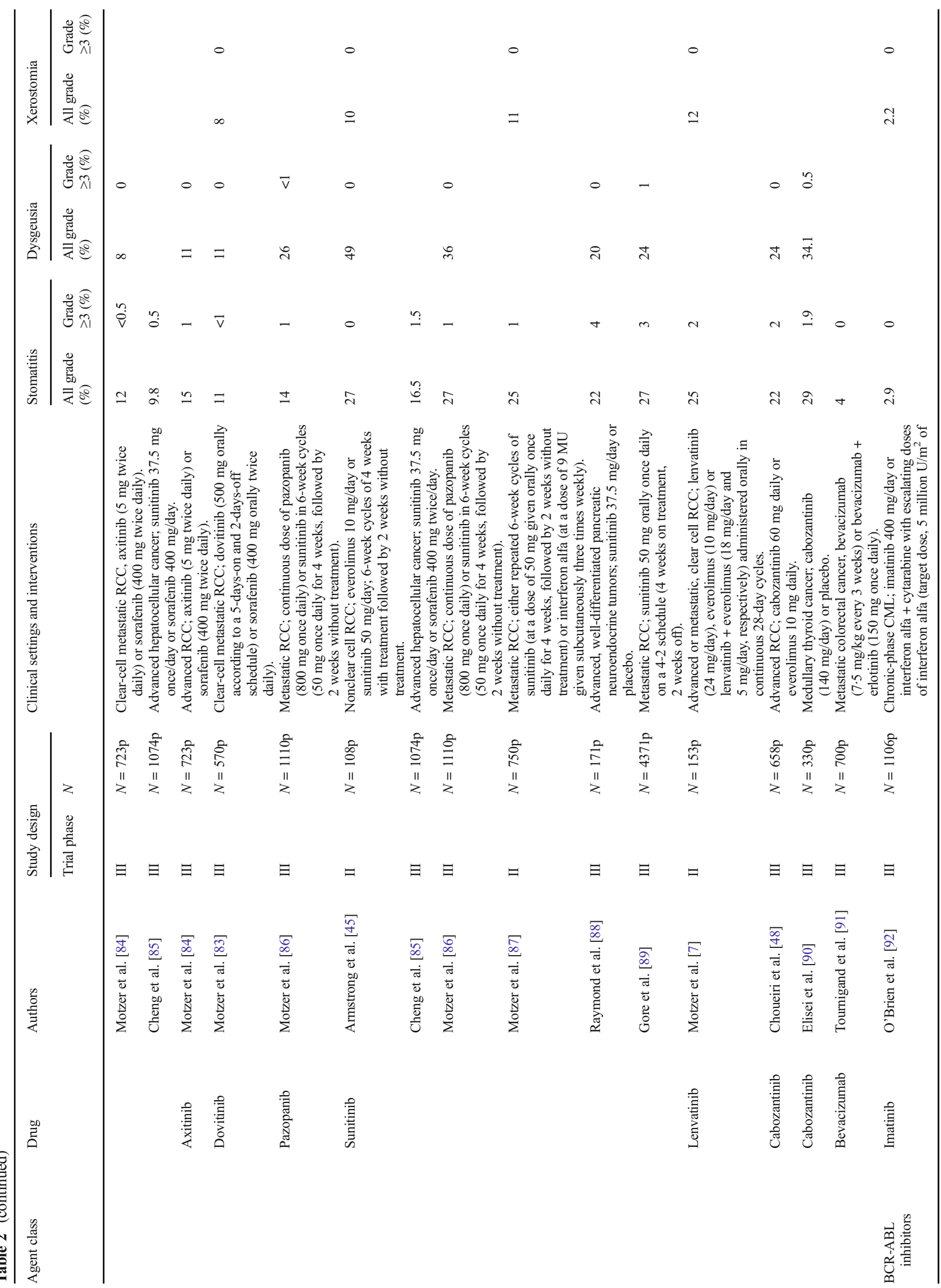




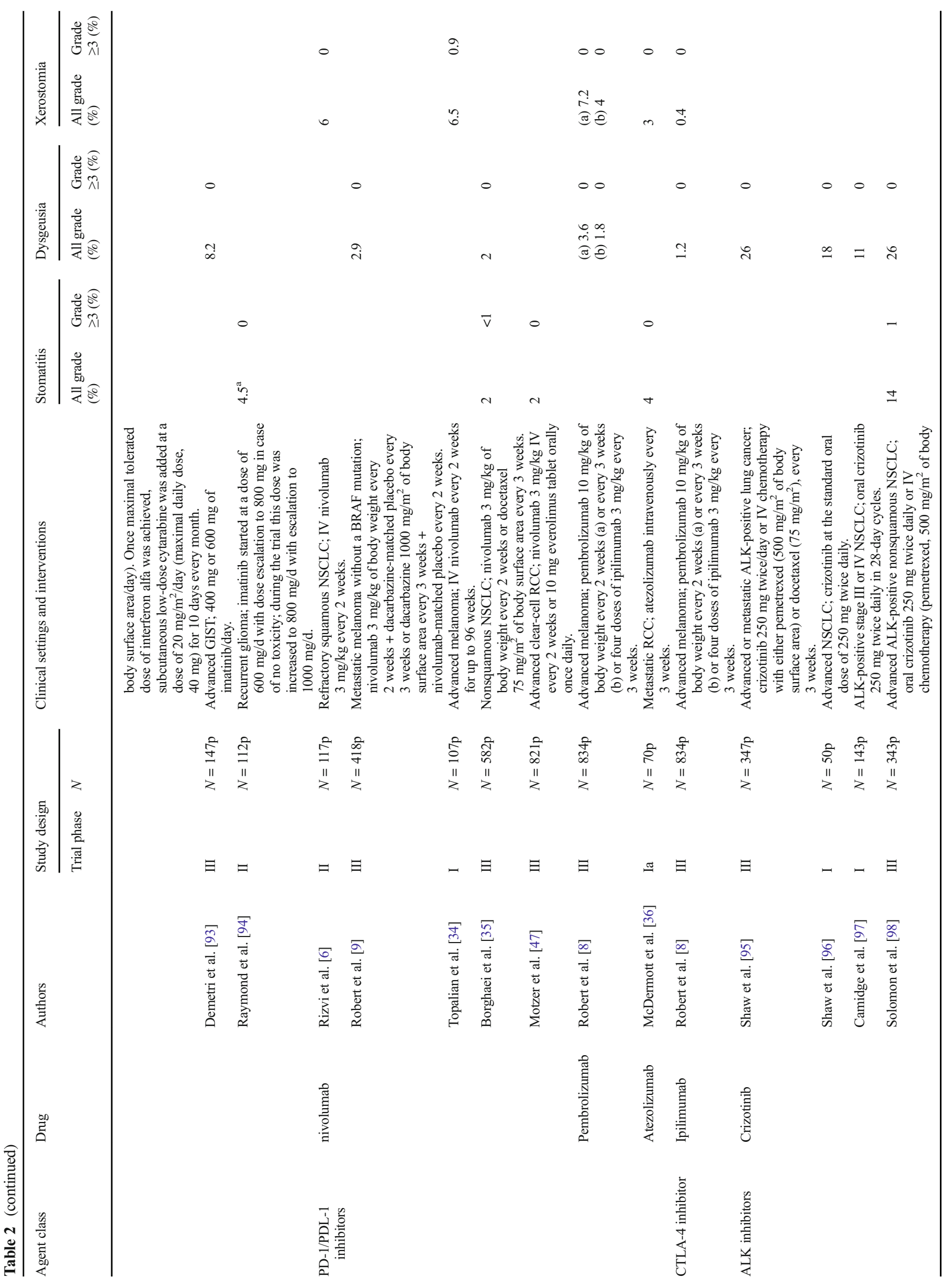


dexamethasone mouth rinse $(0.1 \mathrm{mg} / \mathrm{mL}))$ is the preferred treatment in case of multiple lesions or lesions that are difficult to reach for local application [33]. For limited lesions that can be reached for topical application, high potency corticosteroids (clobetasol $0.05 \%$ gel or cream) is an alternative. In cases where the lesion does not resolve, a combination of intralesional steroid injections (e.g., triamcinolone) and clobetasol $0.05 \%$ gel or cream should be used for treatment. The association of low-level laser therapy (wavelength of 633-685 or 780-830 nm, power output of between 10 and $150 \mathrm{~mW}$, energy density 2 $3 \mathrm{~J} / \mathrm{cm}^{2}$, and no more than $6 \mathrm{~J} / \mathrm{cm}^{2}$ on the tissue surface treated) [113] with topical corticosteroids provides some immediate pain relief and may promote healing of the ulcerations. These data need to be confirmed by prospective studies.

For highly painful (grade $\geq 3$ ), intolerable grade 2 or recurrent mIAS, dose reduction or treatment interruption (see below) and systemic corticosteroids should be considered (high-dose pulse therapy with 30 $60 \mathrm{mg}$ or $1 \mathrm{mg} / \mathrm{kg}$ oral prednisone/prednisolone for 1 week, followed by dose tapering over the second week) [33], while continuing topical interventions. Antifungal therapy may be administrated on a case by case basis [112].

For moderate pain management, anesthetic mouthwash (lidocaine viscous, 2\%), topical analgesic (e.g., doxepin rinse), coating agents or systemic analgesics can be helpful. Topical nonsteroidal anti-inflammatory drugs (amlexanox 5\% oral paste) or paracetamol, in combination with an immediate release oral opioid or fast acting fentanyl preparation, have been proposed as management options. In case of severe pain, other types of analgesic administration routes should be considered [33].

Dose reduction, interruption, or discontinuation (see Table 4)

mIAS may also be managed by dose adjustments. The severity and/or the recurrence of the lesions as well as the time needed to recover will determine whether full dosing can be resumed or whether dose reduction or discontinuation is required [101, 102, 110, 114, 115].

\section{Dysgeusia}

Incidence Everolimus also frequently causes dysgeusia, which has been reported in 9 to $32 \%$ of treated patients [43-45, 48] (Table 2). However, no dose adjustment is generally necessary (Table 2 ). 

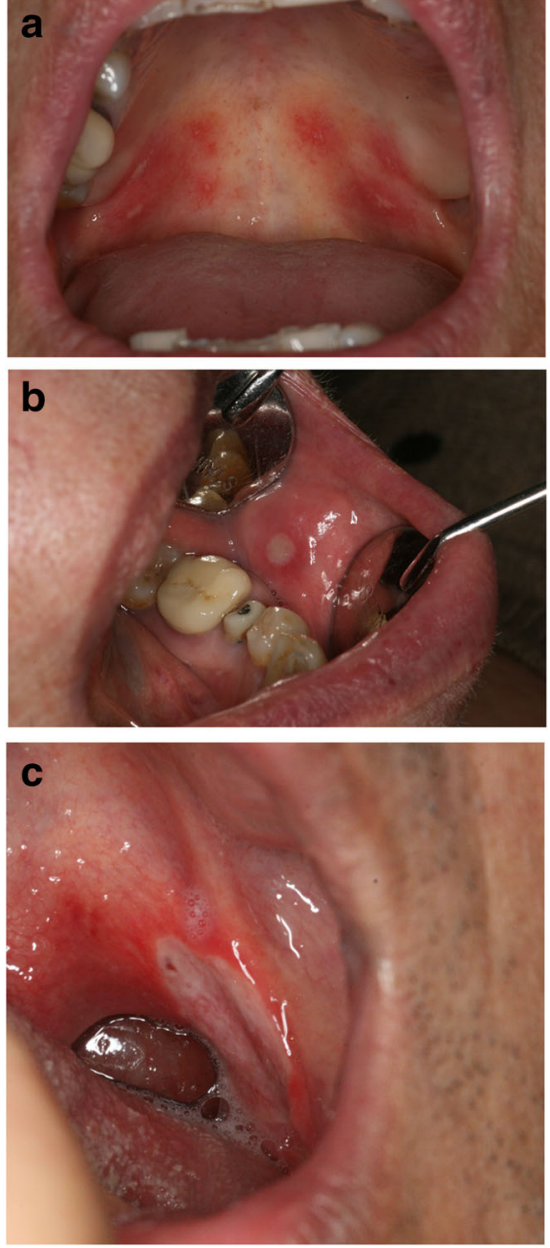

Fig. 1 a Multiple mIAS of the soft palate with mTOR inhibitor (everolimus). b Typical mIAS with an erythematous halo on nonkeratinized mucosa (everolimus). c A major aphthous-like ulceration with everolimus (mIAS)

Although less frequently described, dysgeusia can also be induced by temsirolimus [116].

Management As dysgeusia is benign, it is frequently overlooked. Nevertheless, the impact on patients' quality of life can be significant, with a higher risk of malnutrition and weight

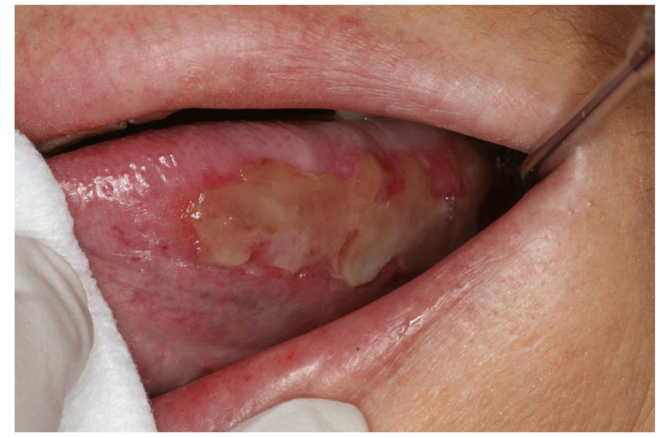

Fig. 2 Widespread mucositis of the lateral ventral side of the tongue induced by chemotherapy (nonkeratinized mucosa)
Table 3 General supportive care measures to prevent mucositis

Basic oral care and oral hygiene recommendations:

- Tooth brushing two or three times a day with an ultra-soft or soft toothbrush with fluoride toothpaste (in case of burning, use minimally flavored toothpaste, e.g., children's toothpaste/gel, dry mouth children's toothpaste/gel)

- Flossing/interdental cleaning after each meal

- Mouth washing with bland solutions four to six times a day (sterile water, normal saline, or sodium bicarbonate)

- Cleaning removable dental prostheses

- Consider oral moisturizers

- To avoid:

- Alcohol-containing rinses and toothpaste with sodium lauryl sulfate

- Alcohol or peroxidase containing mouthwash products

- Antifungal or antimicrobial products without specific indications

- Spicy, acidic, hard, crunchy and/or high temperature food

- Alcoholic drinks

- Tobacco

Oral examination by specialist practitioner:

- Before oncologic treatment: preoperative dental and periodontal screening with treatment as appropriate

- Elimination of traumatic factors (dental or prosthetic origin)

- During and after treatment: regular dental and periodontal examination

loss [117-121]. To date, there is no standardized preventive or curative treatment for dysgeusia [122] and symptomatic dietary measures should be considered (Table 5). Weight monitoring is recommended. The management of contributing factors is also crucial (e.g., smoking, alcoholism, poor oral hygiene, oropharyngeal infections) [121].

\section{Other toxicities}

Xerostomia has been reported in only one comparative study, in which it occurred in $6 \%$ of everolimus-treated patients [7] (Table 2). It is generally mild in this context. No cases of temsirolimus-associated xerostomia have been reported. Basic oral care and dietary recommendations associated with artificial saliva substitutes (moisturizing spray, glycerol-based oral spray) should be recommended if the symptoms severely impact health-related quality of life (Table 5).

Rare cases of osteonecrosis of the jaw have been very sporadically reported with everolimus [123] mostly when it has been used in association with antiresorptive agents [124].

\section{EGFR and pan-HER inhibitors (Table 1)}

Agents targeting the epidermal growth factor receptor (EGFR or HER1) also represent an important strategy in the management of many cancers (colorectal, lung, head and neck, and 
Table 4 Modified management algorithm for mIAS

Grade* 1
Erythema of mucosa with asymptomatic or mild
symptoms

Grade* 2

Patchy ulceration with moderate pain but no interference with oral intake

Grade* 3

Confluent ulcerations or pseudomembranes with severe pain interfering with oral intake

Grade* 4

Tissue necrosis, significant spontaneous bleeding with symptoms associated with life-threatening circumstances
Supportive cares: basic oral care ${ }^{\mathrm{a}}$ and symptomatic management in case of mild symptom (steroid mouthwash)

No dietary modifications

Continue mTOR inhibitor

Monitor for change in severity

Symptomatic management and supportive cares: basic oral care ${ }^{\mathrm{a}}$, topical steroids, low-level laser therapy (LLLT), modified diet

Dose adjustment:

- If toxicity is tolerable $\rightarrow$ No dose adjustment required

- If toxicity becomes $\quad \rightarrow$ Temporary dose interruption until recovery to intolerable grade $\leq 1$

$\rightarrow$ Reinitiate mTOR at same dose

- If toxicity recurs at grade $2 \rightarrow$ Manage as first grade 3 episode: interrupt mTOR until recovery to grade $\leq 1$

$\rightarrow$ Reinitiate at a lower dose (i.e., $5 \mathrm{mg} /$ day for everolimus)

Monitor for change in severity

Symptomatic management and supportive cares: basic oral care, a systemic corticosteroids, LLLT, morphine mouthwash, modified diet, systemic analgesics

Dose adjustment:

- Temporary dose interruption until recovery to grade $\leq 1$; reinitiate mTOR at a lower dose

- If toxicity recurs at grade $3 \rightarrow$ Manage as grade 4: consider discontinuation

Monitor for change in severity

Permanent discontinuation-supportive measures

Grade* refers to NCI CTCAE v4.0

${ }^{\mathrm{a}}$ Basic oral care: see Table 3

breast cancers). They include monoclonal antibodies (cetuximab, panitumumab) and specific tyrosine kinase inhibitors (erlotinib, gefitinib). This group also includes also multitargeted kinase inhibitors, targeting both the EGF receptor and other receptors of the HER (or ErbB) family, such as afatinib, lapatinib, and dacomitinib.

Given the fundamental role of EGFR in homeostasis of the epidermal and epithelial cells, the therapeutic inhibition of this receptor is associated with cutaneous or mucosal toxicities in the majority of anti-EGFR-treated patients [12, 14, 23, 125, 126].

\section{Mucositis}

\section{Incidence}

EGFR/HER1 tyrosine kinase inhibitors (Table 1)

Oral adverse events induced by tyrosine kinase inhibitors targeting EGFR are less frequently reported than skin toxicities $[125,127]$.
The incidence of mucositis induced by erlotinib in monotherapy varies between 8 and 20\% [58, 65, 67, 68] (Table 2). Similar, although slightly higher, incidence values of 17 to $24 \%$ have been reported for gefitinib $[54,63,64,128]$ (Table 2). Moreover, the incidence rate of high-grade $(\geq 3)$ mucositis has never been reported to exceed $1 \%$, neither with erlotinib nor gefitinib. As a consequence, few treated patients require dose modifications as a result of oral mucositis $[68,128]$.

\section{Pan-HER tyrosine kinase inhibitors (Table 1)}

Conversely, with the new generation of pan-HER tyrosine kinase inhibitors, mucositis appears to be one of the main toxicities, after paronychia, diarrhea, and papulopustular rash [55, 59, 128, 129]. The incidence of all-grade mucositis induced by afatinib appears to be significantly higher than that of erlotinib- or gefitinib-induced mucositis [128] and ranges from 25 to $72.1 \%$ [54-60] (Table 2).

Dacomitinib, another irreversible pan-HER tyrosine kinase inhibitor [69], also induces mucositis more frequently 
Table 5 Main interventions for management of oral toxicities

\begin{tabular}{|c|c|}
\hline Toxicities & Interventions \\
\hline Mucositis/Stomatitis/aphthoid lesions & $\begin{array}{l}\text { Basic oral care }{ }^{\text {a }} \text {, steroids (topical, intralesional, oral), morphine mouthwash, systemic analgesics, } \\
\text { low level } \\
\text { laser therapy (LLLT) } \\
\text { Dose reduction, interruption, or discontinuation to be discussed with the oncologist } \\
\text { Offset of radiotherapy sessions to be discussed with the radiotherapist }\end{array}$ \\
\hline Hyperkeratotic lesions & No specific local interventions; monthly examination and biopsy in case of irregular lesions \\
\hline Pigmentation/mucosal dyschromia & No specific local interventions; monthly examination and biopsy in case of irregular lesions \\
\hline Geographic tongue & $\begin{array}{l}\text { No specific local interventions; avoidance of irritating foods; steroid mouth rinse three times per } \\
\text { day for a few days or tacrolimus cream }(0.1 \%) \text { for painful lesions }\end{array}$ \\
\hline Dysgeusia & $\begin{array}{l}\text { Dietary recommendations }{ }^{\mathrm{b}} \\
\text { Dose reduction or changes to medication to be discussed with the oncologist }\end{array}$ \\
\hline Lichenoid lesions & $\begin{array}{l}\text { Topical steroids (clobetasol propionate) for painful lesions; regular oral examinations with } \\
\text { long-term surveillance } \\
\text { Dose reduction, interruption, or discontinuation to be discussed with the oncologist }\end{array}$ \\
\hline Telangiectasia/mucosal hemorrhage & $\begin{array}{l}\text { Basic oral care }{ }^{\mathrm{a}} \\
\text { Dose reduction, interruption, or discontinuation to be discussed with the oncologist }\end{array}$ \\
\hline Xerostomia & $\begin{array}{l}\text { Basic oral care }{ }^{\mathrm{a}} \text {; dietary recommendations } \mathrm{s}^{\mathrm{b}} \\
\text { Hydration, sugar-free gum or candy stimulants; sialogogues: pilocarpine, sulfarlem, civemiline, } \\
\text { bethanechol; artificial saliva substitutes (palliation); thermal water. }\end{array}$ \\
\hline Dysesthesia & $\begin{array}{l}\text { Basic oral care }{ }^{\text {a }} \text { avoidance of irritating foods and symptomatic relief through topical analgesics. } \\
\text { Medications for neuropathy (clonazepam, gabapentin, antidepressants). }\end{array}$ \\
\hline Osteonecrosis of the jaw & $\begin{array}{l}\text { Basic oral care }{ }^{\mathrm{a}} \\
\text { Depending on the stage: antibacterial mouthwash, pain medication, antibiotics, pentoxifylline, } \\
\text { vitamin E, LLLT. } \\
\text { Conservative measures or surgical debridement can be successful at early stages. } \\
\text { Extensive resection is solely indicated in cases of extended necrosis. }\end{array}$ \\
\hline
\end{tabular}

${ }^{\text {a }}$ Basic oral care: see Table 3

${ }^{\mathrm{b}}$ Dietary recommendations: frequent drinks between meals, maintaining good oral hygiene, chewing slowly, diversifying and favoring foods for which flavor is not too distorted, and further enhancing the flavor of food using seasonings and flavorings, consuming cold foods, and avoiding overly fragrant foods

than erlotinib or gefitinib [65] and is associated with an allgrade incidence of about $40 \%$, similar to that of afatinib $[69,70]$ (Table 2). In addition, high-grade ( $\geq 3$ ) mucositis induced by afatinib and dacomitinib may occur in 3 to $8.7 \%$ of treated patients $[54-59,65,69,70]$ (Table 2), which may lead to more frequent dose reductions or discontinuation of the treatment.

\section{Monoclonal antibodies targeting EGFR (Table 1)}

Mucositis appears to occur less frequently with cetuximab or panitumumab monotherapy than with tyrosine kinase inhibitors [30]. These monoclonal antibodies, however, are seldom used as a monotherapy and are usually combined with chemotherapeutic regimens and/or radiation therapy. In one comparative phase III study, the incidence of all-grade mucositis was $7 \%$ in patients treated with cetuximab and $5 \%$ in those treated with panitumumab $(<1 \%$ of grade 3 in both groups) [72] (Table 2). High-grade ( $\geq 3$ ) mucositis was also noted in less than $1 \%$ of patients in an earlier study of patients treated with cetuximab monotherapy [71] (Table 2).

Cetuximab or panitumumab in combination with chemotherapy

Cetuximab and panitumumab are most often used in association with chemotherapy (fluorouracil, cisplatin, folfox, or folfiri chemotherapeutic regimens), particularly when being used for the treatment of advanced colorectal and head and neck cancers. Cetuximab and panitumumab when combined with chemotherapy both significantly increase the risk of developing mucositis of any grade compared to chemotherapy alone $[77-79,81,82,130$, 131] (Table 2), with a relative risk of high-grade $(\geq 3)$ 
mucositis ranging from 2.69 [131] to 3.44 [130].

Cetuximab in association with head and neck radiation therapy

The incidence of high-grade $(\geq 3)$ mucositis is high when cetuximab is combined with radiotherapy (about 60\%) $[73,75,132]$. The main pivotal studies $[73,75,132]$ (Table 2), however, indicate that the addition of cetuximab to radiotherapy does not have a significant impact on the incidence of high-grade $(\geq 3)$ mucositis in comparison to radiotherapy alone [73-75] (Table 2). More recently, Bonner et al. reported that, regardless of p16 status, the addition of cetuximab to cervical radiotherapy did not impact the incidence, time to onset, severity, or duration of mucositis [132] (Table 2).

However, our experience and that of other authors [133] indicates that a higher incidence of severe mucositis is commonly observed with this therapeutic combination. The same tendency is observed when combining cetuximab with head and neck radio-chemotherapy, versus head and neck radio-chemotherapy alone [76] (Table 2). Finally, the incidence of high-grade ( $\geq 3) \mathrm{mu}-$ cositis also seems to be higher when cetuximab is used in combination with radiotherapy than when chemotherapy is used in combination with radiotherapy in head and neck cancer [74] (Table 2).

Clinical presentation In most cases, HER inhibitor-induced mucositis in monotherapy corresponds to a moderate erythema with limited and superficial ulcers (Fig. 3a-c), occurring shortly after treatment introduction [21, 125, 133]. This form of mucositis sometimes takes on the appearance of aphthouslike lesions, although these lesions are less typical than those described above with mTOR inhibitors. All areas of the nonkeratinized oral mucosa may be involved. Lip lesions are quite common, including erythema, erosions, cracks [129], and angular cheilitis [134]. Deeper mucosal ulcerations are occasionally noted and more common when used in combination with cytotoxic therapies. Associated symptoms may range from mild tenderness to pain and difficulties with food intake $[125,134]$.

Head and neck radiotherapy alone is associated with mucosal lesions strictly confined onto the irradiation fields. These lesions involve both keratinized (Fig. 3d) and nonkeratinized mucosa. The addition of cetuximab to cervical radiotherapy for locally advanced squamous cell carcinoma is also associated with severe lesions involving both nonkeratinized and keratinized areas. Paradoxically, anterior and labial mucosal involvement (Fig. 3e) is more common, even though these locations generally receive a lower total dose of irradiation [135]. These lesions are frequently multiple and polycyclic and often associated with significant functional impairment. Interestingly, mucosal pain may present with limited mucosal change. Similarly, the association of monoclonal antibodies targeting EGFR with chemotherapy is associated with more severe mucosal involvement (Fig. 3f).

Management As for mIAS, prevention of EGFR inhibitorassociated mucositis relies on maintaining good oral hygiene resulting from basic oral care interventions (Table 3 ) and prior elimination of outbreaks and sources of local trauma [106, 125]. Treatment guidelines were initially based on the
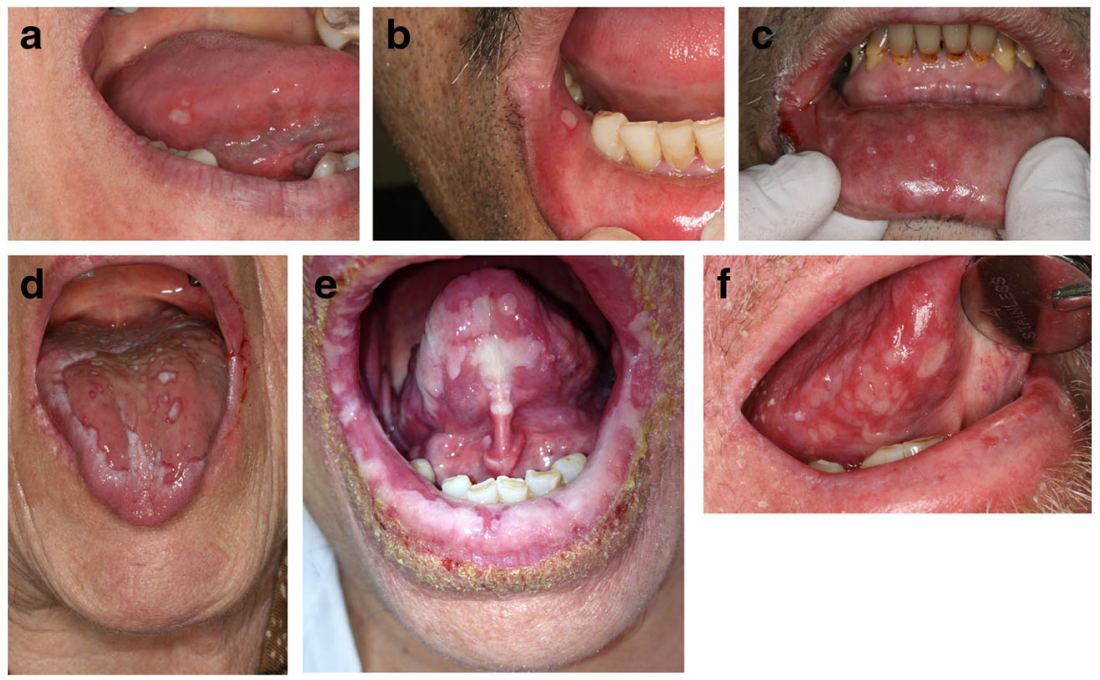

Fig. 3 a Grade 1 mucositis with panitumumab (monoclonal antibody targeting EGFR). b Mucositis induced by afatinib (pan-HER tyrosine kinase inhibitor). c Mucositis involving the labial mucosa induced by erlotinib in monotherapy (anti EGFR). d Diffuse radio-induced

mucositis affecting the keratinized mucosa (dorsum of the tongue). $\mathbf{e}$ High-grade $\geq 3$ mucositis induced by the association of head and neck radiotherapy and cetuximab. f Mucositis induced by cetuximab and chemotherapy (carboplatin and 5FU) in combination 
MASCC guidelines for the management of cytotoxic chemotherapy- and radiotherapy-induced mucositis [107, 125]. The latest ESMO clinical practice guidelines [33] suggest, as for mIAS, using steroids (topical, intralesional or systemic) as the first-line treatment for mucositis induced by antiEGFR therapy. Like mIAS, the use of low-level laser therapy [113] and $0.2 \%$ morphine mouthwash or doxepin rinse may improve control of symptoms and pain particularly patients with grade $\geq 3$ mucositis, treated with cetuximab combined with chemotherapy and/or head and neck radiotherapy [33].

Dose adjustment—offset of radiotherapy session

In general, no dose adjustment is needed for EGFR tyrosine kinase inhibitor-associated grade 1 or 2 mucositis. For patients with grade 3 mucositis, temporary discontinuation of treatment may be necessary. The EGFR tyrosine kinase inhibitor treatment can resume at half the initial dose once mucositis has improved to grade 2, and then be increased as long as there is no worsening of symptoms [129].

Cessation of cetuximab therapy is recommended for patients with grade $\geq 3$ mucositis associated with the combined use of cetuximab and head and neck radiotherapy [136]. Generally, the radiation dose or schedule is not compromised by such events [136].

\section{Other oral toxicities}

Dysgueusia and xerostomia are mainly reported with new generation HER tyrosine kinase inhibitors. Dysgeusia has been described in 6 to $15 \%$ of patients treated with dacomitinib and afatinib [55, 69, 70] (Table 2). In addition, 8 to $14 \%$ of patients treated with dacomitinib have been reported to develop xerostomia $[69,70]$ (Table 2).

\section{Angiogenesis inhibitors (Table 1)}

This class of targeted therapies is characterized by its inhibitory effect on tumor neoangiogenesis. It includes monoclonal antibodies that directly inhibit vascular endothelial growth factor (VEGF) (bevacizumab, ramucirumab) and tyrosine kinase inhibitors that target angiogenic receptors (vascular endothelial growth factor receptor (VEGFR), platelet-derived growth factor receptor (PDGFR)), and other signaling pathways (sunitinib, sorafenib, pazopanib, axitinib, cabozantinib).

The main oral toxicities reported in pivotal studies include nonspecific stomatitis, dysgeusia, and xerostomia, which may occur alone or in association. Approximately one quarter of patients treated with multitargeted antiangiogenic kinase inhibitors develop an oral adverse event within the first 2 months of starting therapy [25]. Sunitinib and sorafenib are the two drugs that are most frequently associated with oral adverse events
[25], but oral toxicities have also been frequently reported with cabozantinib, a new multitargeted kinase inhibitor.

Dose adjustment $(<10 \%$ of treated patients) $[25,137]$ and treatment discontinuation (about $1 \%$ of treated patients) $[25$, 137] due to oral toxicities are rarely needed.

In contrast, bevacizumab and ramucirumab-induced stomatitis is uncommon.

\section{Stomatitis}

Incidence In the main pivotal studies [7, 45, 48, 51, 83-90, 138] (Table 2), the incidence of all-grade stomatitis induced by angiogenesis inhibitors ranges from 7 to $29 \%$, depending on the drug used. Comparative studies underlines that the incidence of all-grade angiogenesis inhibitor-associated stomatitis is lower than that of all-grade mIAS [7, 28, 45, 48, 51] (Table 2).

With sunitinib, stomatitis appears to be one of the most frequent adverse events after diarrhea, fatigue, and nausea [89, 139]. Main pivotal studies have reported that the incidence of any grade stomatitis ranges from 16.5 to $27 \%$ with sunitinib [45, 85-89] (Table 2). The incidence of any grade stomatitis associated with sunitinib appears to be higher than that of stomatitis associated with other multitargeted antiangiogenic kinase inhibitors, in particular sorafenib-for which the incidence of all-grade stomatitis is reported to range from 7 to $19 \%$ [51, 83-85] (Table 2).

On the other hand, the incidence of all-grade stomatitis with cabozantinib is similar to that reported with sunitinib, having been reported in 22 to $29 \%$ of treated patients [ 48 , 90] (Table 2).

The incidence of high-grade $(\geq 3)$ stomatitis has never been reported to exceed $4 \%$ with any multitargeted angiogenesis inhibitor [7, 45, 48, 83, 84, 86-89, 139] (Table 2).

Clinical presentation The broad term "stomatitis" has been used to describe mucosal injuries or toxicities, such as mucosal sensitivity, taste alterations, dry mouth, and necrosis of jaw associated with angiogenesis inhibitors [26]. However, the stomatitis induced by this therapeutic family is more of a diffuse mucosal hypersensitivity/dysesthesia [25], in some cases associated with moderate erythema [28] or painful inflammation of the oral mucosa (including burning mouth, discomfort induced by hot or spicy foods) [25]. Such symptoms appear quite rapidly in the first weeks of treatment [28, 140] and gradually disappear $[21,25]$. In some cases, well-limited ulcerations of the nonkeratinized mucosa were also noted (Fig. 4). Unusually, the stomatitis may manifest as linear lingual ulcers of the nonkeratinized mucosa, particularly with sunitinib or sorafenib $[21,137]$.

Management Management of angiogenesis inhibitor-induced stomatitis currently relies on the same prophylactic and 


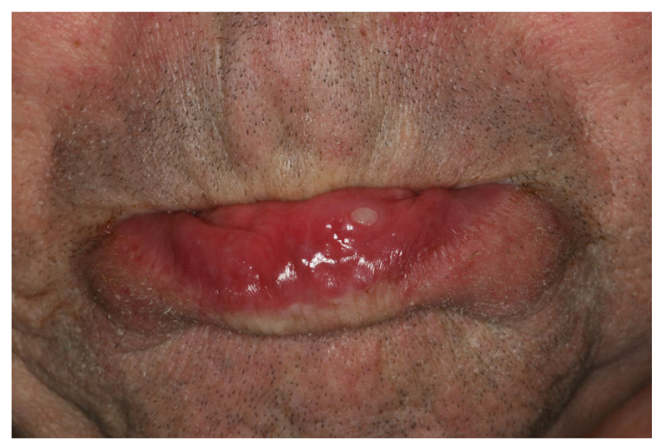

Fig. 4 Well-limited ulceration of the nonkeratinized mucosa with sunitinib (multikinase angiogenesis inhibitor)

curative interventions as described for mIAS or stomatitis induced by EGFR inhibitors (Table 5). Mucosal sensitivity may require dietary modifications, such as avoiding irritating foods and tobacco [25].

\section{Dysgeusia}

Dysgeusia appears to be the second most frequent oral adverse event [25] induced by multitargeted antiangiogenic kinase inhibitors. Taste changes are most often reported with sunitinib and cabozantinib, for which the incidence of all-grade dysgeusia ranges from 20 to $49 \%$ [45, 86-89] and 24 to $34 \%$ of treated patients $[48,90]$, respectively (Table 2). High-grade dysgeusia is clearly uncommon, occurring in below $1 \%$ of treated patients [7, 45, 48, 83, 84, 86-89, 138] (Table 2).

Comparative studies indicate that dysgeusia is more common in patients treated with angiogenesis inhibitors than in those treated with mTOR inhibitors [45, 48] (Table 2).

\section{Benign migratory glossitis}

Patients treated with angiogenesis inhibitors may also develop benign migratory glossitis or geographic tongue. This adverse event was initially described with bevacizumab [141], and we have reported the occurrence of similar lesions with sorafenib and sunitinib [142]. These lesions gradually regress after treatment discontinuation (Fig. 5a, b). We have also observed geographic tongue with pazopanib (Fig. 6) and axitinib. The impact of these events remains unclear [143]. Induced benign migratory glossitis can be moderately painful but usually does not require any treatment modification or specific local treatment [21] (Table 5).

\section{Other oral toxicities}

Xerostomia Depending on the series, 4 to $12 \%$ of patients treated with multitargeted antiangiogenic tyrosine kinase inhibitors develop grade 1 to 2 xerostomia [7, 45, 83, 87] (Table 2).
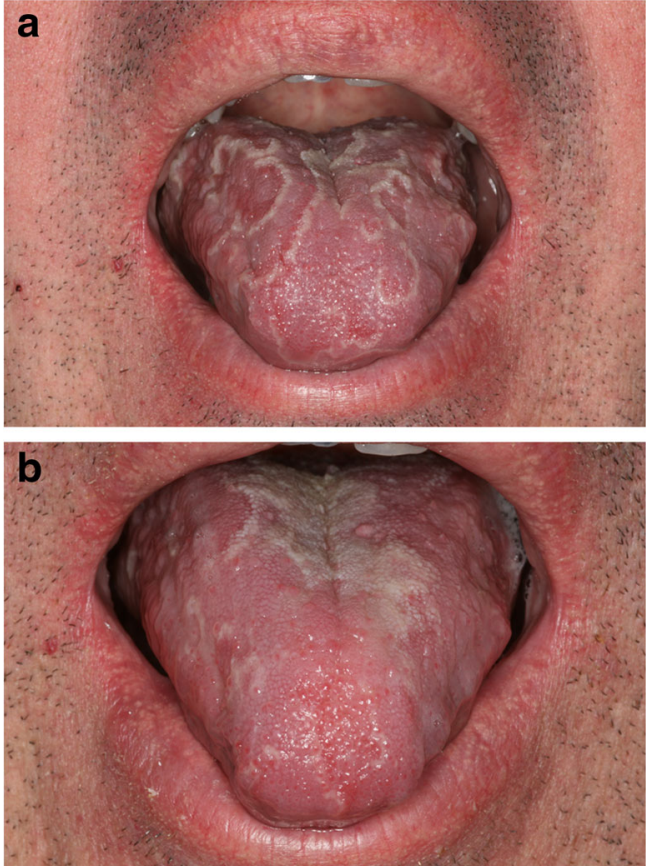

Fig. 5 a Geographic tongue induced by bevacizumab (12 months after treatment introduction). b Significant improvement after bevacizumab discontinuation

Bleeding and delayed healing The inhibition of VEGF or its receptors by angiogenesis inhibitors (sorafenib, sunitinib, vandetanib, axitinib, bevacizumab, etc.) induces significant changes in vascular permeability and can promote mucocutaneous bleeding [144]. Between 20 and $40 \%$ of patients treated with bevacizumab reported moderate bleeding, mostly of the nasal mucosa $[12,138]$. Delayed wound healing can also occur with antiangiogenic agents (sunitinib, bevacizumab); these adverse events should be considered before oral surgery.

Medication related osteonecrosis of the jaw (MRONJ) In oncology, MRONJ is known to occur with antiresorptive agents (bisphosphonates-zoledronic acid, pamidronate, and inhibitor of receptor activator of nuclear factor $\mathrm{kB}$ ligand (RANKL), denosumab) and occurs in 3 to $10 \%$ of treated patients depending on the indication (osseous metastases or myeloma) [145]. The association of these drugs with

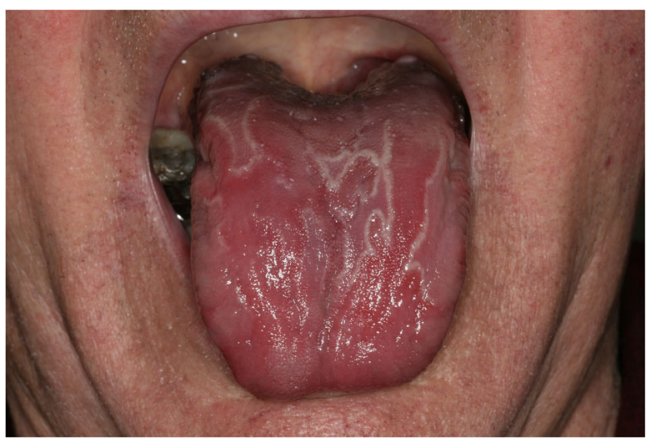

Fig. 6 Geographic tongue with pazopanib 
antiangiogenic targeted therapies (sunitinib, bevacizumab) increases the risk to develop MRONJ (Fig. 7) [145, 146] more often after oral surgery [147-149]. Few data of MRONJ are also reported with sorafenib, cabozantinib, alfibercept, and mTOR inhibitor monotherapy [124, 147]. MRONJ remains an underdiagnosed adverse event because of inadequate or restrictive diagnostic criteria [147] and because early lesions may have few symptoms. Strategies for management rely on expert opinion [150]. Depending on the stage, antibacterial mouthwashes, pain medication, and antibiotics may be recommended. Conservative measures or surgical debridement can be successful during the early stages. Extensive resection of necrotic bone is indicated solely in cases of extended necrosis [148] (Table 5).

Recommendations for oral surgery

Before introduction of antiangiogenic treatment, patients should undergo oral screening (including a comprehensive oral exam with radiographs), be informed about maintaining oral hygiene and should receive all necessary dental treatments [151]. The dentist should contact the oncologist before any oral surgery is carried out on patients treated with angiogenesis inhibitors. Dental/ periodontal management should be limited to unavoidable surgical interventions during the course of antiangiogenic treatment. The therapeutic window should always be evaluated during antiangiogenic targeted therapy. Monoclonal antibodies and tyrosine kinase inhibitors might be stopped at least 2 and 1 week, respectively, before oral surgery. The treatment can be reinitiated after mucosal healing. Dental screening and preoperative dental treatments remain key management approaches for prevention of MRONJ and delayed healing [149-151].

Mucosal yellow discoloration Although quite exceptional, yellow diffuse staining of the oral mucosa (Fig. 8) can be observed with sunitinib. This induced coloration occurs

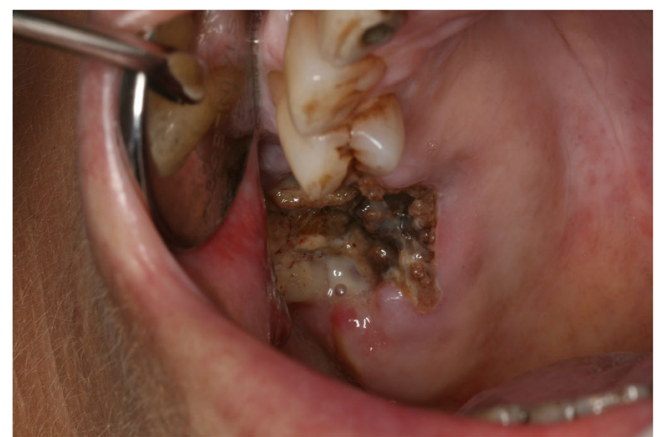

Fig. 7 Osteonecrosis of the jaw induced by the association of bevacizumab and denosumab

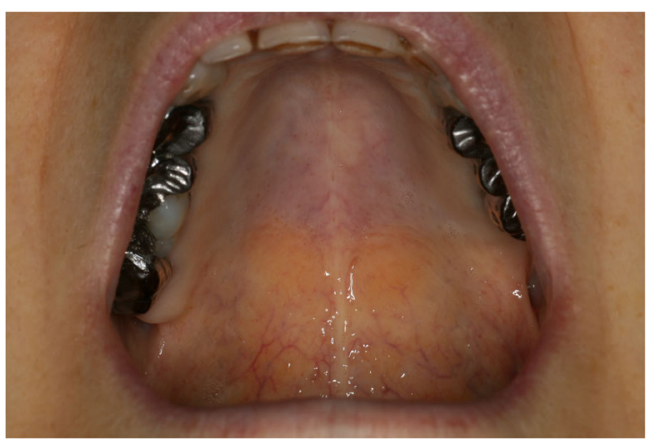

Fig. 8 Yellow pigmentation of the soft palate with sunitinib

frequently in the skin and appears to be directly related to the color of the drug itself. It is associated with characteristic colored urine [152]. No specific management is required.

Hyperkeratotic lesions Finally, we have observed sporadic cases of oral hyperkeratotic lesions in patients treated with the pan-RAF inhibitor, sorafenib. In addition, this multitargeted antiangiogenic tyrosine kinase inhibitor has recently been reported to induce development of oral squamous cell carcinoma [144].

\section{BCR-ABL inhibitor: imatinib (Table 1)}

Imatinib is a first-generation BCR-ABL inhibitor targeting cKIT and the PDGFR. It is frequently associated with oral toxicities which are now well-characterized.

\section{Lichenoid reactions}

Development of oral lichenoid reactions [153-155] (Fig. 9) is the most frequent oral adverse event of imatinib. It can occur in isolation or in association with lichenoid nail or skin lesions [155-158]. This toxicity has only rarely been reported in the literature [155]. Our clinical experience indicates that these mucosal lesions are relatively frequent but probably underestimated due to their typically asymptomatic nature. The lesions are polymorphic, combining more or less characteristic reticular/striated lesions with symptomatic ulcerative,

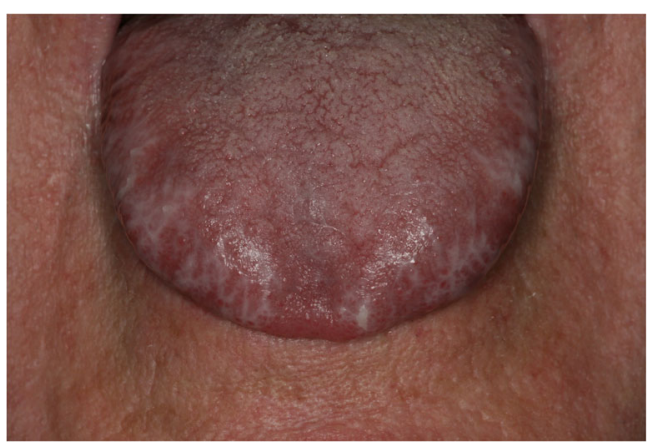

Fig. 9 Lichenoid lesion of the border of the tongue induced by imatinib 
erosive, or atrophic lesions. They are preferentially localized on the buccal or lingual mucosa [153, 157-159].

These lesions gradually develop after a few months of treatment $[154,155,159]$. Their discovery is often fortuitous, and thus, systematic oral examination of the oral cavity is required in patients treated with imatinib.

Given the potential risk of malignant transformation of lichenoid reactions, regular monitoring of these lesions is recommended [160]; however, it is not known if the lichenoid changes seen with imatinib may have malignant risk. Symptomatic forms are generally treated with high potency topical corticosteroid therapy, and imatinib treatment can be continued in almost all cases.

To our knowledge, there have been no reports of similar lesions with new generation BCR-ABL inhibitors, such as dasatinib, nilotinib, ponatinib, or bosutinib.

\section{Pigmentary changes}

More unusually, a fairly typical "blue-gray" asymptomatic hyperpigmentation of the hard palate may be noted in patients treated with imatinib (Fig. 10) [161-166]. Pigmentation in other locations has been described in anecdotal reports [167]. Discovery of the oral hyperpigmentation is usually fortuitous, and the time of onset is unknown. The pathophysiological mechanism seems similar to that of hyperpigmentation due to antimalarials (drug metabolite deposition in the mucosa and complex formation with hemosiderin or melanin) [18]. Direct inhibition of c-kit (which is physiologically expressed in the oral mucosa) by imatinib has been also implicated in this mechanism by some authors $[161,162]$.

To your knowledge, this reaction has not been described with new generation BCR-ABL inhibitors.

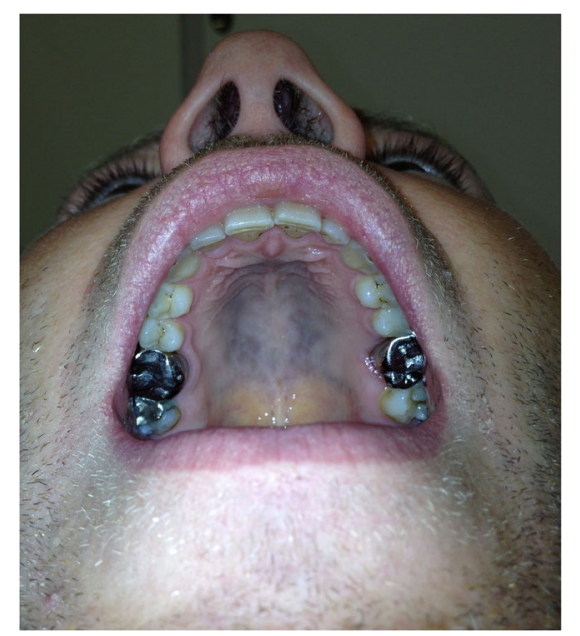

Fig. 10 Typical blue/gray hyperpigmentation of the hard palate with imatinib

\section{Immune checkpoint inhibitors (Table 1)}

Use of cytotoxic T-lymphocyte-associated antigen 4 (CTLA-4) and programmed cell death-1 (PD1) and its ligand (PDL-1) inhibitors, either as single agents or in combination, results in a distinct spectrum of toxicities, mostly related to activation of the immune system [168]. Among the multiple IRae reported with these drugs, dermatologic toxicities represent the most frequent adverse events [19, 20, 168].

Use of both PD-L1 and PD-1 (nivolumab, pembrolizumab) inhibitors has been found to be associated with nonspecific stomatitis or oral mucosal inflammation in sporadic cases $[35,36,47,169,170]$, but no grade $\geq 3$ adverse events have been reported. Recently, more characteristic oral lesions with PD-1 or PD-L1 inhibitors have been described [20, 38, 171, 172].

\section{Xerostomia}

Xerostomia (generally grade 1-2) has been reported in about $6 \%$ of patients treated with nivolumab [6,34] (Table 2) for melanoma (Fig. 11a) and in between about 4 and $7.2 \%$ of pembrolizumab-treated patients [8] (Table 2). In addition, we have observed severe grade 3 xerostomia in exceptional cases (Fig. 11b). The xerostomia shows clinical features of a

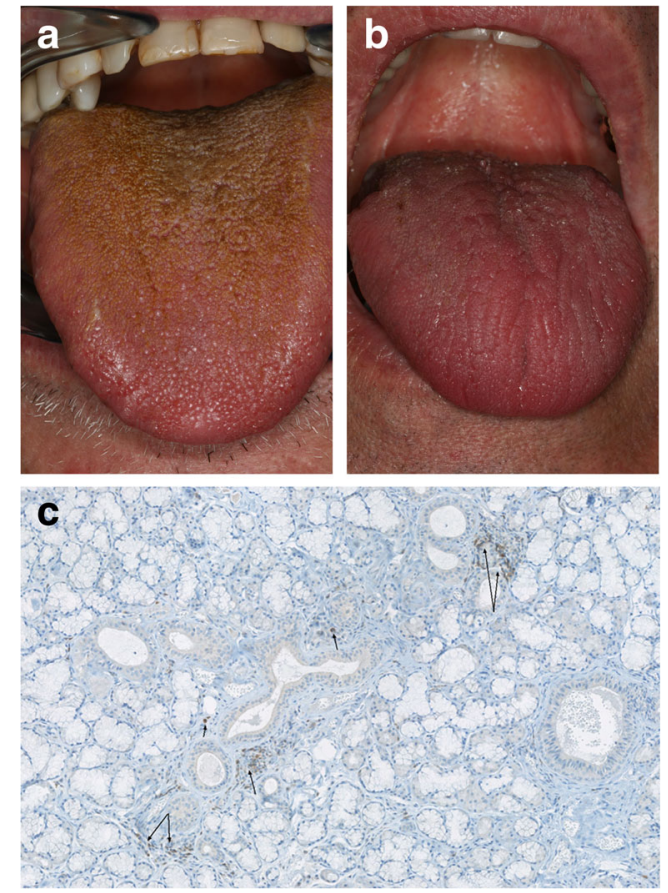

Fig. 11 a Xerostomia with associated black hairy tongue induced by anti-PD-1 (nivolumab). b Severe Sjögren-like syndrome (nivolumab). c Lymphohistiocytic infiltrate surrounding salivary glands with positive PD-1 immunostaining (Sjögren-like syndrome, nivolumab) (original magnification $\times 10$ ) 
Gougerot-Sjögren-like syndrome, with cytotoxic T-lymphocyte infiltration of accessory salivary glands (Fig. 11c). However, anti SSA and anti SSB antibodies screening is generally negative.

\section{Dysgeusia}

Moderate dysgeusia (grade 1 or 2) has been noted in less than $3 \%$ of PD-1 and PD-L-1-treated patients [8, 9, 35, 47] (Table 2). Xerostomia and dysgeusia appear less commonly with the anti-CTLA-4 agent, ipilimumab [8] (Table 2).

\section{Lichenoid reactions}

Schaberg et al. [172] reported one case of lichenoid lesion with PDL-1 inhibitor therapy and Hofmann et al. [171] reported one case of oral lichen planus with pembrolizumab. We have also observed several cases of mucosal lesions, which were clinically and histologically consistent with oral lichenoid lesions, developing as a result of treatment with PD-1 and PD-L-1 [20]. These lesions generally occurred several months after treatment induction. Histopathology and immunophenotypic analysis of the lichenoid lesions associated with anti-PD1 and anti-PDL-1 therapy seem to reveal greater histiocytic infiltrate than that observed in similar nondrug-related lichenoid reactions (i.e., lichen planus, lichen planus-like keratoses) [172].

Lesions may appear as whitish papules (confluent in places), in reticular or linear streaks, and are sometimes associated with erythema. The dorsal and lateral sides of the tongue, lips, gingiva, hard palate, or buccal mucosae (Fig. $12 \mathrm{a}-\mathrm{c}$ ) can be involved. Patients may report pain or soreness but the lesions can also be asymptomatic. The perianal area or vulva can also be affected [172]. Topical corticosteroids should be considered if lesions are painful (Table 5).

\section{BRAF inhibitors (Table 1)}

Vemurafenib and dabrafenib are two FDA-approved selective BRAF inhibitors for the treatment of mutated BRAF $^{\mathrm{V} 600}$ metastatic melanoma. When used in monotherapy, dermatologic adverse events, particularly hyperkeratotic lesions, represent the most common toxicities of these targeted therapies. A broad spectrum of induced hyperkeratotic lesions has been reported, including verrucous papillomas, keratosis pilaris-like rashes, and malignant epithelial tumors, such as keratoacanthoma or squamous cell carcinoma [173-175]. Hyperkeratotic lesions are probably induced by proliferation of wild-type BRAF keratinocytes, secondary to the paradoxical
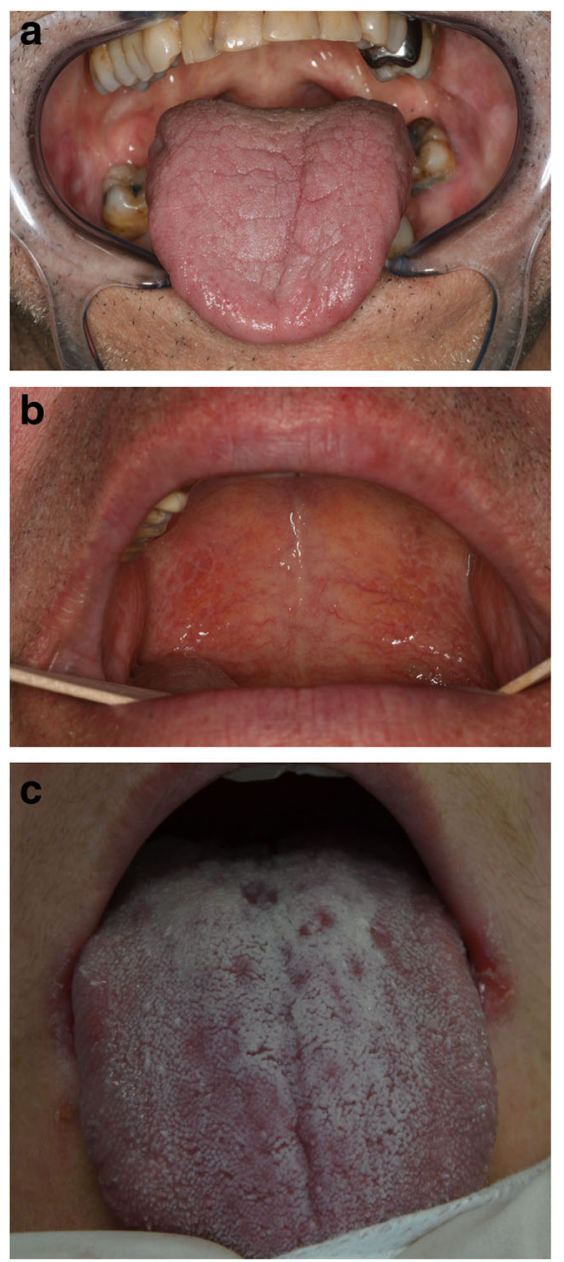

Fig. 12 a Lichenoid lesion of the dorsum of the tongue with nivolumab (anti-PDL-1). b Lichenoid lesion of the soft palate induced by nivolumab. c Lichenoid reaction of the dorsum of the tongue

activation of the intracellular mitogen-activated protein (MAP) kinase pathway [174, 176, 177].

The oral toxicity of BRAF inhibitors has only been described recently $[31,178,179]$. This toxicity is characterized by the sometimes rapid development of asymptomatic hyperkeratotic multifocal mucosal lesions on both the keratinized and nonkeratinized mucosa, predominantly located on the linea alba (Fig. 13a), the marginal gingiva, the hard palate (Fig. 13b), the lateral borders of the tongue (Fig. 13c), or the labial mucosa. All lesions exhibit similar features and sometimes have a verrucous or papillomatous appearance [31]. We have recently reported the first case of squamous cell carcinoma (SCC) on vemurafenib-induced hyperkeratotic lesions of the labial mucosa [31]. Due to the usually asymptomatic nature of these lesions and the lack of systematic oral examinations in treated patients, the incidence of induced hyperkeratotic lesions is not known.

As the incidence of BRAF inhibitor-induced cutaneous SCC is clearly higher than that of oral SCC, oral examinations 

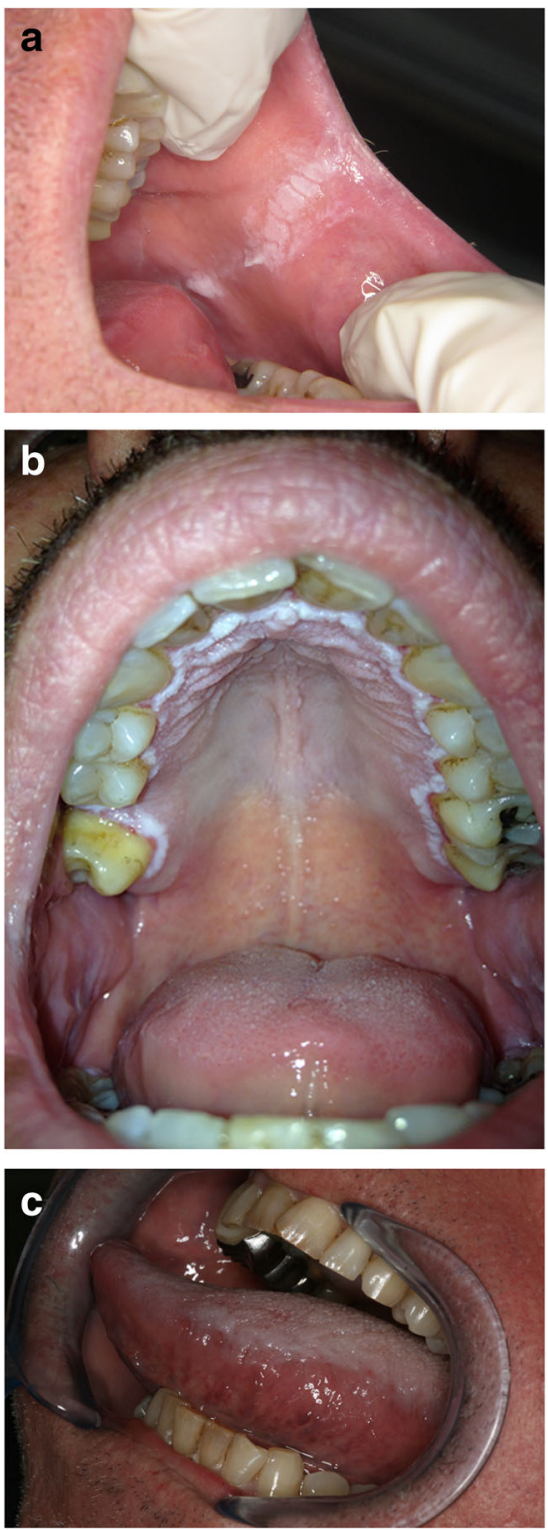

Fig. 13 a Hyperkeratotic lesions of the linea alba induced by a BRAF inhibitor (anti-BRAF vemurafenib). b Hyperkeratotic lesions of the marginal gingiva and hard palate (anti-BRAF dabrafenib). c Hyperkeratotic lesion involving the dorsum of the tongue (anti-BRAF vemurafenib)

should be carried out on a regular basis at all follow up visits and oral hyperkeratotic lesions should be treated with caution and biopsy is recommended in case of doubt. Furthermore, anecdotal observations of vemurafenib-induced inflammatory gingival hyperplasia have been recently reported [178, 179].

BRAF inhibitors are now mostly used in combination with MEK inhibitors (vemurafenib with cobimetinib, and dabrafenib with trametinib). By blocking the downstream MAP kinase pathway, MEK inhibitors significantly restrict the development of secondary hyperkeratotic lesions $[13$, 180]. Therefore, it is anticipated that these mucosal lesions will be less reported in the near future.
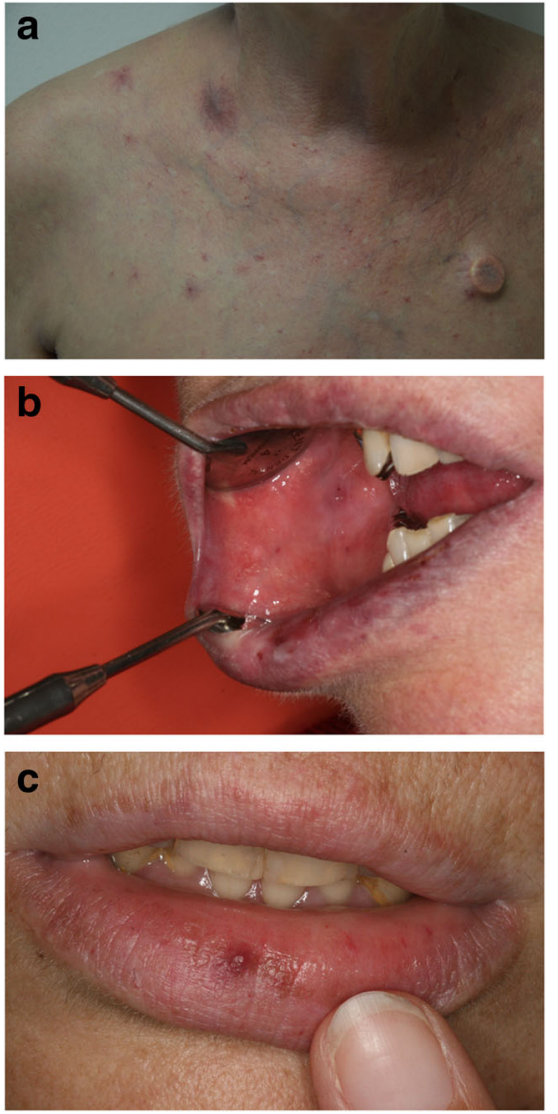

Fig. 14 a Cutaneous telangiectasias induced by the glycoconjugate monoclonal antibody TDM1. b, c Mucosal telangiectasias of the buccal and labial mucosa with TDM1

\section{Other targeted therapies with oral toxicities}

\section{ALK inhibitors (Table 1)}

Crizotinib is an oral small-molecule tyrosine kinase inhibitor targeting the anaplastic lymphoma kinase (ALK), MET, and ROS1 tyrosine kinases. The main reported oral toxicity induced by this therapy is moderate dysgeusia (grade 1 or 2) (Table 2), which affects 11 to $26 \%$ of treated patients [95-98] (Table 2). Moreover, all-grade stomatitis occurs in less than $15 \%$ of treated patients, with no reports of any high-grade $\geq 3$ cases [98] (Table 2).

\section{Hedgehog pathway inhibitors (Table 1)}

Vismodegib is a first-in-class, oral, selective Hedgehog pathway inhibitor, FDA-approved for the treatment of locallyadvanced or metastatic basal cell carcinomas. One of the most frequent reported toxicities is grade $1 / 2$ dysgeusia, for which the incidence ranges from 51 to $84 \%$ depending on the series $[13,99,100,181]$ (Table 2). High-grade $\geq 3$ dysgeusia has been reported in about $2 \%$ of treated patients (Basset-Seguin et al. 100). Furthermore, vismodegib also induces ageusia 
[100] (Table 2) in 22\% of treated patients, with an incidence of $2 \%$ for high-grade $\geq 3$ toxicity. Dysgeusia is the second most common vismodegib-induced adverse event after muscle spasms $[100,181]$. It can lead to treatment interruption $(6 \%$ of patients) and generally occurs within the first 6 months of therapy [181].

Management (Table 5) Due to the high incidence of vismodegib-induced taste changes, informing and educating patients about this adverse event is required at initiation of vismodegib therapy. Early nutritional screening and routine nutritional counseling from a dietician should be considered in order to prevent significant weight loss. Investigation of the nature and severity of taste changes require study in order that approaches to management can be developed [182].

\section{Trastuzumab-emtansine (T-DM-1) (Table 1)}

We have recently described the development of cutaneous (Fig. 14a) and mucosal telangiectasias (Fig. 14b, c), mimicking Osler-Weber-Rendu syndrome [183, 184], with the antibody-drug conjugate ado-trastuzumab emtansine (T-DM1, FDA-approved for the treatment of HER2+ metastatic breast cancer).

These oral mucosal lesions can be observed on the whole mucosa (palate, tongue, lips, and jugal mucosa). They blanch during diascopy and appear dome-shaped with surrounding small radiating dilated vessels. On the skin, they appear as spider telangiectasias.

Epistaxis, digestive, or gynecological bleeding occurs in about $30 \%$ of T-DM-1-treated patients, without the systematic presence of associated thrombocytopenia. These bleeding events may, at least in part, be linked to the mucosal vascular malformations [184]. Given the potential risk of hemorrhage, screening for mucosal telangiectasia is recommended (Table 5).

\section{Conclusion}

Oral toxicities of targeted therapies and immune checkpoint inhibitors develop less frequently than the more common and prominent cutaneous toxicities. However, the oral changes may be underreported using general toxicity scales and relying upon patient report. These oral adverse events also appear to be less symptomatic than chemotherapy-induced mucositis but may require dose adjustments. Oral lesions can be clinically quite specific, and systematic examination of the oral mucosa is recommended as part of the monitoring regimen of patients treated with these drugs. Physicians should be aware of these induced mucosal changes. Early recognition and appropriate management are necessary in order to limit dose modifications and preserve patients' quality of life. Study of approach to management of oral toxicities is required to improve guidance for improved patient care.

\section{References}

1. Sacco AG, Cohen EE (2015) Current treatment options for recurrent or metastatic head and neck squamous cell carcinoma. J Clin Oncol 33:3305-3313

2. Sampat KR, O'Neil B (2013) Antiangiogenic therapies for advanced hepatocellular carcinoma. Oncologist 18:430-438

3. Kundu SK, Nestor M (2012) Targeted therapy in head and neck cancer. Tumour Biol 33:707-721

4. Johnson DB, Pollack MH, Sosman JA (2016) Emerging targeted therapies for melanoma. Expert Opin Emerg Drugs 21:195-207

5. Postow MA, Chesney J, Pavlick AC, Robert C, Grossmann K, McDermott D et al (2015) Nivolumab and ipilimumab versus ipilimumab in untreated melanoma. N Engl J Med 372:2006-2017

6. Rizvi NA, Mazières J, Planchard D, Stinchcombe TE, Dy GK, Antonia SJ et al (2015) Activity and safety of nivolumab, an antiPD-1 immune checkpoint inhibitor, for patients with advanced, refractory squamous non-small-cell lung cancer (CheckMate 063): a phase 2, single-arm trial. Lancet Oncol 16:257-265

7. Motzer RJ, Hutson TE, Glen H, Michaelson MD, Molina A, Eisen $T$ et al (2015) Lenvatinib, everolimus, and the combination in patients with metastatic renal cell carcinoma: a randomised, phase 2, open-label, multicentre trial. Lancet Oncol 16:1473-1482

8. Robert C, Schachter J, Long GV, Arance A, Grob JJ, Mortier L et al (2015) Pembrolizumab versus ipilimumab in advanced melanoma. N Engl J Med 372:2521-2532

9. Robert C, Long GV, Brady B, Dutriaux C, Maio M, Mortier L et al (2015) Nivolumab in previously untreated melanoma without BRAF mutation. N Engl J Med 372:320-330

10. Pennock GK, Chow LQ (2015) The evolving role of immune checkpoint inhibitors in cancer treatment. Oncologist 20:812-822

11. Wang J, Reiss KA, Khatri R, Jaffee E, Laheru D (2015) Immune therapy in GI malignancies: a review. J Clin Oncol 33:1745-1753

12. Macdonald JB, Macdonald B, Golitz LE, LoRusso P, Sekulic A (2015) Cutaneous adverse effects of targeted therapies: part I: inhibitors of the cellular membrane. J Am Acad Dermatol 72: 203-218

13. Macdonald JB, Macdonald B, Golitz LE, LoRusso P, Sekulic A (2015) Cutaneous adverse effects of targeted therapies: part II: inhibitors of intracellular molecular signaling pathways. J Am Acad Dermatol 72:221-236

14. Robert C, Sibaud V, Mateus C, Cherpelis BS (2012) Advances in the management of cutaneous toxicities of targeted therapies. Semin Oncol 39:227-240

15. Robert C, Mateus C, Spatz A, Wechsler J, Escudier B (2009) Dermatologic symptoms associated with the multikinase inhibitor sorafenib. J Am Acad Dermatol 60:299-305

16. Fakih M, Vincent M (2010) Adverse events associated with antiEGFR therapies for the treatment of metastatic colorectal cancer. Curr Oncol 17(Suppl 1):S18-S30

17. Robert C, Soria JC, Spatz A, Le Cesne A, Malka D, Pautier P et al (2005) Cutaneous side-effects of kinase inhibitors and blocking antibodies. Lancet Oncol 6:491-500

18. Reyes-Habito CM, Roh EK (2014) Cutaneous reactions to chemotherapeutic drugs and targeted therapy for cancer: part II. Targeted therapy. J Am Acad Dermatol 71:217.e1-217.e11 
19. Naidoo J, Page DB, Li BT, Connell LC, Schindler K, Lacouture ME et al (2015) Toxicities of the anti-PD-1 and anti-PD-L1 immune checkpoint antibodies. Ann Oncol 26:2375-2391

20. Sibaud V, Meyer N, Lamant L, Vigarios E, Mazieres J, Delord JP (2016) Dermatologic complications of anti-PD-1/PD-L-1 immune checkpoint antibodies. Curr Opinion Oncol 28:254-263

21. Sibaud V, Boralevi F, Vigarios E, Fricain JC (2014) Oral toxicity of targeted anticancer therapies. Ann Dermatol Venereol 141:354 363 [Article in French]

22. Martins F, de Oliveira MA, Wang Q, Sonis S, Gallottini M, George $S$ et al (2013) A review of oral toxicity associated with mTOR inhibitor therapy in cancer patients. Oral Oncol 49:293-298

23. Watters AL, Epstein JB, Agulnik M (2011) Oral complications of targeted cancer therapies: a narrative literature review. Oral Oncol 47:441-448

24. Jensen SB, Peterson DE (2014) Oral mucosal injury caused by cancer therapies: current management and new frontiers in research. J Oral Pathol Med 43:81-90

25. Yuan A, Kurtz SL, Barysauskas CM, Pilotte AP, Wagner AJ, Treister NS (2015) Oral adverse events in cancer patients treated with VEGFR-directed multitargeted tyrosine kinase inhibitors. Oral Oncol 51:1026-1033

26. Al-Ansari S, Zecha JA, Barasch A, de Lange J, Rozema FR, Raber-Durlacher JE (2015) Oral mucositis induced by anticancer therapies. Curr Oral Health Rep 2:202-211

27. Sonis S, Treister N, Chawla S, Demetri G, Haluska F (2010) Preliminary characterization of oral lesions associated with inhibitors of mammalian target of rapamycin in cancer patients. Cancer 116:210-215

28. Boers-Doets CB, Epstein JB, Raber-Durlacher JE, Ouwerkerk J, Logan RM, Brakenhoff JA et al (2012) Oral adverse events associated with tyrosine kinase and mammalian target of rapamycin inhibitors in renal cell carcinoma: a structured literature review. Oncologist 17:135-144

29. Gomez-Fernandez C, Garden BC, Wu S, Feldman DR, Lacouture ME (2012) The risk of skin rash and stomatitis with the mammalian target of rapamycin inhibitor temsirolimus: a systematic review of the literature and meta-analysis. Eur J Cancer 48:340-346

30. Elting LS, Chang YC, Parelkar P, Boers-Doets CB, Michelet M, Hita $G$ et al (2013) Risk of oral and gastrointestinal mucosal injury among patients receiving selected targeted agents: a meta-analysis. Support Care Cancer 21:3243-3254

31. Vigarios E, Lamant L, Delord JP, Fricain JC, Chevreau C, Barrés B et al (2015) Oral squamous cell carcinoma and hyperkeratotic lesions with BRAF inhibitors. Br J Dermatol 172:1680-1682

32. De Oliveira MA, Martins E, Martins F, Wang Q, Sonis S, Demetri $\mathrm{G}$ et al (2011) Clinical presentation and management of mTOR inhibitor-associated stomatitis. Oral Oncol 47:998-1003

33. Peterson DE, Boers-Doets CB, Bensadoun RJ, Herrstedt J, Guidelines Committee ESMO (2015) Management of oral and gastrointestinal mucosal injury: ESMO Clinical Practice Guidelines for diagnosis, treatment, and follow-up. Ann Oncol 26:v139-v151

34. Topalian SL, Sznol M, McDermott DF, Kluger HM, Carvajal RD, Sharfman WH et al (2014) Survival, durable tumor remission, and long-term safety in patients with advanced melanoma receiving nivolumab. J Clin Oncol 32:1020-1030

35. Borghaei H, Paz-Ares L, Horn L, Spigel DR, Steins M, Ready NE et al (2015) Nivolumab versus docetaxel in advanced non squamous non-small-cell lung cancer. N Engl J Med 373:1627-1639

36. McDermott DF, Sosman JA, Sznol M, Massard C, Gordon MS, Hamid O et al (2016) Atezolizumab, an anti-programmed deathligand 1 antibody, in metastatic renal cell carcinoma: long-term safety, clinical activity, and immune correlates from a phase Ia study. J Clin Oncol 34:833-842
37. Jackson LK, Johnson DB, Sosman JA, Murphy BA, Epstein JB (2015) Oral health in oncology: impact of immunotherapy. Support Care Cancer 23:1-3

38. Shi VJ, Rodic N, Gettinger S, Leventhal JS, Neckman JP, Girardi $\mathrm{M}$ et al (2016) Clinical and histologic features of lichenoid mucocutaneous eruptions due to anti-programmed cell death 1 and antiprogrammed cell death ligand 1 immunotherapy. JAMA Dermatol 152:1128-1136

39. Shameem R, Lacouture M, Wu S (2015) Incidence and risk of high-grade stomatitis with mTOR inhibitors in cancer patients. Cancer Investig 33:70-77

40. Campistol JM, de Fijter JW, Flechner SM, Langone A, Morelon E, Stockfleth E (2010) mTOR inhibitor-associated dermatologic and mucosal problems. Clin Transpl 24:149-156

41. Vargo CA, Berger MJ, Phillips G, Mrozek E (2016) Occurrence and characterization of everolimus adverse events during first and subsequent cycles in the treatment of metastatic breast cancer. Support Care Cancer 24:2913-2918

42. Rugo HS, Hortobagyi GN, Yao J, Pavel M, Ravaud A, Franz D et al (2016) Meta-analysis of stomatitis in clinical studies of everolimus: incidence and relationship with efficacy. Ann Oncol 27: 519-525

43. Yao JC, Shah MH, Ito T, Bohas CL, Wolin EM, Van Cutsem E et al (2011) Everolimus for advanced pancreatic neuroendocrine tumors. N Engl J Med 364:514-523

44. Baselga J, Campone M, Piccart M, Burris HA, Rugo HS, Sahmoud T et al (2012) Everolimus in postmenopausal hormone-receptor-positive advanced breast cancer. N Engl J Med 366:520-529

45. Armstrong AJ, Halabi S, Eisen T, Broderick S, Stadler WM, Jones RJ et al (2016) Everolimus versus sunitinib for patients with metastatic non-clear cell renal cell carcinoma (ASPEN): a multicentre, open-label, randomised phase 2 trial. Lancet Oncol 17:378-388

46. André F, O'Regan R, Ozguroglu M, Toi M, Xu B, Jerusalem G et al (2014) Everolimus for women with trastuzumab-resistant, HER2-positive, advanced breast cancer (BOLERO-3): a randomised, double-blind, placebo-controlled phase 3 trial. Lancet Oncol 15:580-591

47. Motzer RJ, Escudier B, McDermott DF, George S, Hammers HJ, Srinivas $S$ et al (2015) Nivolumab versus everolimus in advanced renal-cell carcinoma. N Engl J Med 373:1803-1813

48. Choueiri TK, Escudier B, Powles T, Mainwaring PN, Rini BI, Donskov F et al (2015) Cabozantinib versus everolimus in advanced renal-cell carcinoma. N Engl J Med 373:1814-1823

49. Hudes G, Carducci M, Tomczak P, Dutcher J, Figlin R, Kapoor A et al (2007) Temsirolimus, interferon alfa, or both for advanced renal-cell carcinoma. N Engl J Med 356:2271-2281

50. Wolff AC, Lazar AA, Bondarenko I, Garin AM, Brincat S, Chow L et al (2013) Randomized phase III placebo-controlled trial of letrozole plus oral temsirolimus as first-line endocrine therapy in postmenopausal women with locally advanced or metastatic breast cancer. J Clin Oncol 31:195-202

51. Hutson TE, Escudier B, Esteban E, Bjarnason GA, Lim HY, Pittman KB et al (2014) Randomized phase III trial of temsirolimus versus sorafenib as second-line therapy after sunitinib in patients with metastatic renal cell carcinoma. J Clin Oncol 32:760-767

52. Rini BI, Bellmunt J, Clancy J, Wang K, Niethammer AG, Hariharan $\mathrm{S}$ et al (2014) Randomized phase III trial of temsirolimus and bevacizumab versus interferon alfa and bevacizumab in metastatic renal cell carcinoma: INTORACT trial. J Clin Oncol 32:752-759

53. Ansell SM, Tang H, Kurtin PJ, Koenig PA, Inwards DJ, Shah K et al (2011) Temsirolimus and rituximab in patients with relapsed or refractory mantle cell lymphoma: a phase 2 study. Lancet Oncol $12: 361-368$ 
54. Park K, Tan EH, O'Byrne K, Zhang L, Boyer M, Mok T et al (2016) Afatinib versus gefitinib as first-line treatment of patients with EGFR mutation-positive non-small-cell lung cancer (LUXLung 7): a phase 2B, open-label, randomised controlled trial. Lancet Oncol 17:577-589

55. Miller VA, Hirsh V, Cadranel J, Chen YM, Park K, Kim SW et al (2012) Afatinib versus placebo for patients with advanced, metastatic non-small-cell lung cancer after failure of erlotinib, gefitinib, or both, and one or two lines of chemotherapy (LUX-Lung 1): a phase $2 b / 3$ randomised trial. Lancet Oncol 13:528-538

56. Wu YL, Zhou C, Hu CP, Feng J, Lu S, Huang Y et al (2014) Afatinib versus cisplatin plus gemcitabine for first-line treatment of Asian patients with advanced non-small-cell lung cancer harbouring EGFR mutations (LUX-Lung 6): an open-label, randomised phase 3 trial. Lancet Oncol 15:213-222

57. Machiels JP, Haddad RI, Fayette J, Licitra LF, Tahara M, Vermorken JB et al (2015) Afatinib versus methotrexate as second-line treatment in patients with recurrent or metastatic squamous-cell carcinoma of the head and neck progressing on or after platinum-based therapy (LUX-Head \& Neck 1): an open-label, randomised phase 3 trial. Lancet Oncol 16: 583-594

58. Soria JC, Felip E, Cobo M, Lu S, Syrigos K, Lee KH et al (2015) Afatinib versus erlotinib as second-line treatment of patients with advanced squamous cell carcinoma of the lung (LUX-Lung 8): an open-label randomised controlled phase 3 trial. Lancet Oncol 16: 897-907

59. Sequist LV, Yang JC, Yamamoto N, O’Byrne K, Hirsh V, Mok T et al (2013) Phase III study of afatinib or cisplatin plus pemetrexed in patients with metastatic lung adenocarcinoma with EGFR mutations. J Clin Oncol 31:3327-3334

60. Harbeck N, Huang CS, Hurvitz S, Yeh DC, Shao Z, Im SA et al (2016) Afatinib plus vinorelbine versus trastuzumab plus vinorelbine in patients with HER2-overexpressing metastatic breast cancer who had progressed on one previous trastuzumab treatment (LUX-Breast 1): an open-label, randomised, phase 3 trial. Lancet Oncol 17:357-366

61. Geyer CE, Forster J, Lindquist D, Chan S, Romieu CG, Pienkowski T et al (2006) Lapatinib plus capecitabine for HER2-positive advanced breast cancer. N Engl J Med 355: 2733-2743

62. Goss PE, Smith IE, O'Shaughnessy J, Ejlertsen B, Kaufmann M, Boyle F et al (2013) Adjuvant lapatinib for women with earlystage HER2-positive breast cancer: a randomised, controlled, phase 3 trial. Lancet Oncol 14:88-96

63. Mok TS, Wu YL, Thongprasert S, Yang CH, Chu DT, Saijo N et al (2009) Gefitinib or carboplatin-paclitaxel in pulmonary adenocarcinoma. N Engl J Med 361:947-957

64. Mitsudomi T, Morita S, Yatabe Y, Negoro S, Okamoto I, Tsurutani $\mathrm{J}$ et al (2010) Gefitinib versus cisplatin plus docetaxel in patients with non-small-cell lung cancer harbouring mutations of the epidermal growth factor receptor (WJTOG3405): an open label, randomised phase 3 trial. Lancet Oncol 11:121-128

65. Ramalingam SS, Jänne PA, Mok T, O’Byrne K, Boyer MJ, Von Pawel J et al (2014) Dacomitinib versus erlotinib in patients with advanced-stage, previously treated non-small-cell lung cancer (ARCHER 1009): a randomised, double-blind, phase 3 trial. Lancet Oncol 15:1369-1378

66. Ciuleanu T, Stelmakh L, Cicenas S, Miliauskas S, Grigorescu AC, Hillenbach C et al (2012) Efficacy and safety of erlotinib versus chemotherapy in second-line treatment of patients with advanced, non-small-cell lung cancer with poor prognosis (TITAN): a randomised multicentre, open-label, phase 3 study. Lancet Oncol 13:300-308

67. Zhou C, Wu YL, Chen G, Feng J, Liu XQ, Wang C et al (2011) Erlotinib versus chemotherapy as first-line treatment for patients with advanced EGFR mutation-positive non-small-cell lung cancer (OPTIMAL, CTONG-0802): a multicentre, open-label, randomised, phase 3 study. Lancet Oncol 12:735-742

68. Shepherd FA, Rodrigues Pereira J, Ciuleanu T, Tan EH, Hirsh V, Thongprasert $S$ et al (2005) Erlotinib in previously treated nonsmall-cell lung cancer. N Engl J Med 353:123-132

69. Ellis PM, Shepherd FA, Millward M, Perrone F, Seymour L, Liu G et al (2014) Dacomitinib compared with placebo in pretreated patients with advanced or metastatic non-small-cell lung cancer (NCIC CTG BR.26): a double-blind, randomised, phase 3 trial. Lancet Oncol 15:1379-1388

70. Jänne PA, Ou SH, Kim DW, Oxnard GR, Martins R, Kris MG et al (2014) Dacomitinib as first-line treatment in patients with clinically or molecularly selected advanced non-small-cell lung cancer: a multicentre, open-label, phase 2 trial. Lancet Oncol 15:1433-1441

71. Cunningham D, Humblet Y, Siena S, Khayat D, Bleiberg H, Santoro A et al (2004) Cetuximab monotherapy and cetuximab plus irinotecan in irinotecan-refractory metastatic colorectal cancer. N Engl J Med 351:337-345

72. Price TJ, Peeters M, Kim TW, Li J, Cascinu S, Ruff P et al (2014) Panitumumab versus cetuximab in patients with chemotherapyrefractory wild-type KRAS exon 2 metastatic colorectal cancer (ASPECCT): a randomised, multicentre, open-label, noninferiority phase 3 study. Lancet Oncol 15:569-579

73. Bonner JA, Harari PM, Giralt J, Cohen RB, Jones CU, Sur RK et al (2010) Radiotherapy plus cetuximab for locoregionally advanced head and neck cancer: 5-year survival data from a phase 3 randomised trial, and relation between cetuximab-induced rash and survival. Lancet Oncol 11:21-28

74. Magrini SM, Buglione M, Corvò R, Pirtoli L, Paiar F, Ponticelli P et al (2016) Cetuximab and radiotherapy versus cisplatin and radiotherapy for locally advanced head and neck cancer: a randomized phase II trial. J Clin Oncol 34:427-435

75. Bonner JA, Harari PM, Giralt J, Azarnia N, Shin DM, Cohen RB et al (2006) Radiotherapy plus cetuximab for squamous-cell carcinoma of the head and neck. N Engl J Med 354:567-578

76. Ang KK, Zhang Q, Rosenthal DI, Nguyen-Tan PF, Sherman EJ, Weber RS et al (2014) Randomized phase III trial of concurrent accelerated radiation plus cisplatin with or without cetuximab for stage III to IV head and neck carcinoma: RTOG 0522. J Clin Oncol 32:2940-2950

77. Lordick F, Kang YK, Chung HC, Salman P, Oh SC, Bodoky G et al (2013) Capecitabine and cisplatin with or without cetuximab for patients with previously untreated advanced gastric cancer (EXPAND): a randomised, open-label phase 3 trial. Lancet Oncol 14:490-499

78. Kim ES, Neubauer M, Cohn A, Schwartzberg L, Garbo L, Caton J et al (2013) Docetaxel or pemetrexed with or without cetuximab in recurrent or progressive non-small-cell lung cancer after platinumbased therapy: a phase 3, open-label, randomised trial. Lancet Oncol 14:1326-1336

79. Primrose J, Falk S, Finch-Jones M, Valle J, O'Reilly D, Siriwardena A et al (2014) Systemic chemotherapy with or without cetuximab in patients with resectable colorectal liver metastasis: the New EPOC randomised controlled trial. Lancet Oncol 15: 601-611

80. Vermorken JB, Stöhlmacher-Williams J, Davidenko I, Licitra L, Winquist E, Villanueva C et al (2013) Cisplatin and fluorouracil with or without panitumumab in patients with recurrent or metastatic squamous-cell carcinoma of the head and neck (SPECTRUM): an open-label phase 3 randomised trial. Lancet Oncol 14:697-710

81. Leone F, Marino D, Cereda S, Filippi R, Belli C, Spadi R et al (2016) Panitumumab in combination with gemcitabine and oxaliplatin does not prolong survival in wild-type KRAS 
advanced biliary tract cancer: a randomized phase 2 trial (VectiBIL study). Cancer 122:574-581

82. Waddell T, Chau I, Cunningham D, Gonzalez D, Okines AF, Okines C et al (2013) Epirubicin, oxaliplatin, and capecitabine with or without panitumumab for patients with previously untreated advanced oesophagogastric cancer (REAL3): a randomised, open-label phase 3 trial. Lancet Oncol 14:481-489

83. Motzer RJ, Porta C, Vogelzang NJ, Sternberg CN, Szczylik C, Zolnierek J et al (2014) Dovitinib versus sorafenib for third-line targeted treatment of patients with metastatic renal cell carcinoma: an open-label, randomised phase 3 trial. Lancet Oncol 15:286-296

84. Motzer RJ, Escudier B, Tomczak P, Hutson TE, Michaelson MD, Negrier S et al (2013) Axitinib versus sorafenib as second-line treatment for advanced renal cell carcinoma: overall survival analysis and updated results from a randomised phase 3 trial. Lancet Oncol 14:552-562

85. Cheng AL, Kang YK, Lin DY, Park JW, Kudo M, Qin S et al (2013) Sunitinib versus sorafenib in advanced hepatocellular cancer: results of a randomized phase III trial. J Clin Oncol 31:4067-4075

86. Motzer RJ, Hutson TE, Cella D, Reeves J, Hawkins R, Guo J et al (2013) Pazopanib versus sunitinib in metastatic renal-cell carcinoma. N Engl J Med 369:722-731

87. Motzer RJ, Hutson TE, Tomczak P, Michaelson MD, Bukowski RM, Rixe O et al (2007) Sunitinib versus interferon alfa in metastatic renal-cell carcinoma. N Engl J Med 356:115-124

88. Raymond E, Dahan L, Raoul JL, Bang YJ, Borbath I, LombardBohas C et al (2011) Sunitinib malate for the treatment of pancreatic neuroendocrine tumors. N Engl J Med 364:501-513

89. Gore ME, Szczylik C, Porta C, Bracarda S, Bjarnason GA, Oudard S et al (2009) Safety and efficacy of sunitinib for metastatic renal-cell carcinoma: an expanded-access trial. Lancet Oncol 10:757-763

90. Elisei R, Schlumberger MJ, Müller SP, Schöffski P, Brose MS, Shah MH et al (2013) Cabozantinib in progressive medullary thyroid cancer. J Clin Oncol 31:3639-3646

91. Tournigand C, Chibaudel B, Samson B, Scheithauer W, Vernerey D, Mésange $P$ et al (2015) Bevacizumab with or without erlotinib as maintenance therapy in patients with metastatic colorectal cancer (GERCOR DREAM; OPTIMOX3): a randomised, open-label, phase 3 trial. Lancet Oncol 16:1493-1505

92. O'Brien SG, Guilhot F, Larson RA, Gathmann I, Baccarani M, Cervantes $F$ et al (2003) Imatinib compared with interferon and low-dose cytarabine for newly diagnosed chronic-phase chronic myeloid leukemia. N Engl J Med 348:994-1004

93. Demetri GD, von Mehren M, Blanke CD, Van den Abbeele AD, Eisenberg B, Roberts PJ et al (2002) Efficacy and safety of imatinib mesylate in advanced gastrointestinal stromal tumors. N Engl J Med 347:472-480

94. Raymond E, Brandes AA, Dittrich C, Fumoleau P, Coudert B, Clement PM et al (2008) Phase II study of imatinib in patients with recurrent gliomas of various histologies: a European Organisation for Research and Treatment of Cancer Brain Tumor Group Study. J Clin Oncol 26:4659-4665

95. Shaw AT, Kim DW, Nakagawa K, Seto T, Crinó L, Ahn MJ et al (2013) Crizotinib versus chemotherapy in advanced ALK-positive lung cancer. N Engl J Med 368:2385-2394

96. Shaw AT, Ou SH, Bang YJ, Camidge DR, Solomon BJ, Salgia R et al (2014) Crizotinib in ROS1-rearranged non-small-cell lung cancer. N Engl J Med 371:1963-1971

97. Camidge DR, Bang YJ, Kwak EL, Iafrate AJ, Varella-Garcia M, Fox SB et al (2012) Activity and safety of crizotinib in patients with ALK-positive non-small-cell lung cancer: updated results from a phase 1 study. Lancet Oncol 13:1011-1019
98. Solomon BJ, Mok T, Kim DW, Wu YL, Nakagawa K, Mekhail T et al (2014) First-line crizotinib versus chemotherapy in ALKpositive lung cancer. N Engl J Med 371:2167-2177

99. Sekulic A, Migden MR, Oro AE, Dirix L, Lewis KD, Hainsworth JD et al (2012) Efficacy and safety of vismodegib in advanced basal-cell carcinoma. N Engl J Med 366:2171-2179

100. Basset-Seguin N, Hauschild A, Grob JJ, Kunstfeld R, Dréno B, Mortier L et al (2015) Vismodegib in patients with advanced basal cell carcinoma (STEVIE): a pre-planned interim analysis of an international, open-label trial. Lancet Oncol 16:729-736

101. Rugo HS (2016) Dosing and safety implications for oncologists when administering everolimus to patients with hormone receptorpositive breast cancer. Clin Breast Cancer 16:18-22

102. Rugo HS, Pritchard KI, Gnant M, Noguchi S, Piccart M, Hortobagyi $G$ et al (2014) Incidence and time course of everolimus-related adverse events in postmenopausal women with hormone receptor-positive advanced breast cancer: insights from BOLERO-2. Ann Oncol 25:808-815

103. Sonis ST (2009) Mucositis: the impact, biology and therapeutic opportunities of oral mucositis. Oral Oncol 45:1015-1020

104. Sonis ST (2004) The pathobiology of mucositis. Nat Rev Cancer $4: 277-284$

105. Nishimura N, Nakano K, Ueda K, Kodaira M, Yamada S, Mishima Y et al (2012) Prospective evaluation of incidence and severity of oral mucositis induced by conventional chemotherapy in solid tumors and malignant lymphomas. Support Care Cancer 20:2053-2059

106. Elad S, Raber-Durlacher JE, Brennan MT, Saunders DP, Mank AP, Zadik Y et al (2015) Basic oral care for hematologyoncology patients and hematopoietic stem cell transplantation recipients: a position paper from the joint task force of the Multinational Association of Supportive Care in cancer/ International Society of Oral Oncology (MASCC/ISOO) and the European Society for Blood and Marrow Transplantation (EBMT). Support Care Cancer 23:223-236

107. Lalla RV, Bowen J, Barasch A, Elting L, Epstein J, Keefe DM et al (2014) MASCC/ISOO clinical practice guidelines for the management of mucositis secondary to cancer therapy. Cancer 120:1453-1461

108. Peterson ME (2013) Management of adverse events in patients with hormone receptor-positive breast cancer treated with everolimus: observations from a phase III clinical trial. Support Care Cancer 21:2341-2349

109. McGuire DB, Fulton JS, Park J, Brown CG, Correa ME, Eilers J et al (2013) Systematic review of basic oral care for the management of oral mucositis in cancer patients. Support Care Cancer 21: 3165-3177

110. Peterson DE, O'Shaughnessy JA, Rugo HS, Elad S, Schubert MM, Viet CT et al (2016) Oral mucosal injury caused by mammalian target of rapamycin inhibitors: emerging perspectives on pathobiology and impact on clinical practice. Cancer Med 5: 1897-1907

111. Rugo HS, Seneviratne L, Beck JT, Glaspy JA, Peguero JA, Pluard TJ et al. (2016) Prevention of everolimus/exemestane stomatitis in postmenopausal women with hormone receptor-positive metastatic breast cancer using a dexamethasone-based mouthwash: results of the SWISH Trial. ASCO Ann Meeting, Poster, June 3-7 2016 Chicago, Illinois

112. Porta C, Osanto S, Ravaud A, Climent MA, Vaishampayan U, White DA et al (2011) Management of adverse events associated with the use of everolimus in patients with advanced renal cell carcinoma. Eur J Cancer 47:1287-1298

113. Zecha JA, Raber-Durlacher JE, Nair RG, Epstein JB, Elad S, Hamblin MR et al (2016) Low-level laser therapy/ photobiomodulation in the management of side effects of 
chemoradiation therapy in head and neck cancer: part 2: proposed applications and treatment protocols. Support Care Cancer 24:27932805

114. Paplomata E, Zelnak A, O'Regan R (2013) Everolimus: side effect profile and management of toxicities in breast cancer. Breast Cancer Res Treat 140:453-462

115. Porta C, Paglino C, Imariso I, Canipari C, Chen K, Neary M et al (2011) Safety and treatment patterns of multikinase inhibitors in patients with metastatic renal cell carcinoma at a tertiary oncology center in Italy. BMC Cancer 11:105-113

116. Kwitkowski VE, Prowell TM, Ibrahim A, Farrell AT, Justice R (2010) Mitchell SS et al. FDA approval summary: temsirolimus as treatment for advanced renal cell carcinoma Oncologist 15:428-435

117. Tuccori M, Lapi F, Testi A, Ruggiero E, Moretti U, Vannacci A et al (2011) Drug-induced taste and smell alterations: a case/noncase evaluation of an italian database of spontaneous adverse drug reaction reporting. Drug Saf 34:849-859

118. Mosel DD, Bauer RL, Lynch DP, Hwang ST (2011) Oral complications in the treatment of cancer patients. Oral Dis 17:550-559

119. Zabernigg A, Gamper EM, Giesinger JM, Rumpold G, Kemmler G, Gattringer $\mathrm{K}$ et al (2010) Taste alterations in cancer patients receiving chemotherapy: a neglected side effect? Oncologist 15: 913-920

120. Imai H, Soeda H, Komine K, Otsuka K, Shibata H (2013) Preliminary estimation of the prevalence of chemotherapyinduced dysgeusia in Japanese patients with cancer. BMC Palliat Care 12:38

121. Epstein JB, Barasch A (2010) Taste disorders in cancer patients: pathogenesis, and approach to assessment and management. Oral Oncol 46:77-81

122. Nagraj SK, Naresh S, Srinivas K, Renjith George P, Shrestha A, Levenson $D$ et al (2014) Interventions for the management of taste disturbances. Cochrane Database Syst Rev 11:CD010470

123. Kim DW, Jung YS, Park HS, Jung HD (2013) Osteonecrosis of the jaw related to everolimus: a case report. Br J Oral Maxillofac Surg 51:e302-e304

124. Hamadeh IS, Ngwa BA, Gong Y (2015) Drug induced osteonecrosis of the jaw. Cancer Treat Rev 41:455-464

125. Lacouture ME, Anadkat MJ, Bensadoun RJ, Bryce J, Chan A, Epstein JB et al (2011) Clinical practice guidelines for the prevention and treatment of EGFR inhibitor-associated dermatologic toxicities. Support Care Cancer 19:1079-1095

126. Lacouture ME, Lai SE (2006) The PRIDE (papulopustules and/or paronychia, regulatory abnormalities of hair growth, itching, and dryness due to epidermal growth factor receptor inhibitors) syndrome. Br J Dermatol 155:852-854

127. Chen P, Wang L, Liu B, Zhang HZ, Liu HC, Zou Z (2011) EGFRtargeted therapies combined with chemotherapy for treating advanced non-small-cell lung cancer: a meta-analysis. Eur J Clin Pharmacol 67:235-243

128. Burotto M, Manasanch EE, Wilkerson J, Fojo T (2015) Gefitinib and erlotinib in metastatic non-small cell lung cancer: a metaanalysis of toxicity and efficacy of randomized clinical trials. Oncologist 20:400-410

129. Melosky B, Hirsh V (2014) Management of common toxicities in metastatic NSCLC related to anti-lung cancer therapies with EGFR-TKIs. Front Oncol 4:238

130. Miroddi M, Sterrantino C, Simonelli I, Ciminata G, Phillips RS, Calapai G (2015) Risk of grade 3-4 diarrhea and mucositis in colorectal cancer patients receiving anti-EGFR monoclonal antibodies regimens: a meta-analysis of 18 randomized controlled clinical trials. Crit Rev Oncol Hematol 96:355-371

131. Lv ZC, Ning JY, Chen HB (2014) Efficacy and toxicity of adding cetuximab to chemotherapy in the treatment of metastatic colorectal cancer: a meta-analysis from 12 randomized controlled trials. Tumour Biol 35:11741-11750
132. Bonner JA, Giralt J, Harari PM, Baselga J, Spencer S, Bell D et al (2016) Association of human papillomavirus and p16 status with mucositis and dysphagia for head and neck cancer patients treated with radiotherapy with or without cetuximab: assessment from a phase 3 registration trial. Eur J Cancer 64:1-11

133. Tejwani A, Wu S, Jia Y, Agulnik M, Millender L, Lacouture ME (2009) Increased risk of high-grade dermatologic toxicities with radiation plus epidermal growth factor receptor inhibitor therapy. Cancer 115:1286-1299

134. Lacouture ME, Maitland ML, Segaert S, Setser A, Baran R, Fox LP et al (2010) A proposed EGFR inhibitor dermatologic adverse event-specific grading scale from the MASCC skin toxicity study group. Support Care Cancer 18:509-522

135. Pryor DI, Burmeister E, Burmeister BH, Poulsen MG, Porceddu SV (2011) Distinct patterns of stomatitis with concurrent cetuximab and radiotherapy for head and neck squamous cell carcinoma. Oral Oncol 47:984-987

136. Zhu G, Lin JC, Kim SB, Bernier J, Agarwal JP, Vermorken JB et al (2016) Asian expert recommendation on management of skin and mucosal effects of radiation, with or without the addition of cetuximab or chemotherapy, in treatment of head and neck squamous cell carcinoma. BMC Cancer 16:42

137. Kollmannsberger C, Bjarnason G, Burnett P, Creel P, Davis M, Dawson N et al (2011) Sunitinib in metastatic renal cell carcinoma: recommendations for management of non-cardiovascular toxicities. Oncologist 16:543-553

138. Perren TJ, Swart AM, Pfisterer J, Ledermann JA, Pujade-Lauraine E, Kristensen $\mathrm{G}$ et al (2011) A phase 3 trial of bevacizumab in ovarian cancer. N Engl J Med 365:2484-2496

139. Ibrahim EM, Kazkaz GA, Abouelkhair KM, Bayer AM, Elmasri OA (2013) Sunitinib adverse events in metastatic renal cell carcinoma: a meta-analysis. Int J Clin Oncol 18:1060-1069

140. Edmonds K, Hull D, Spencer-Shaw A, Koldenhof J, Chrysou M, Boers-Doets C et al (2012) Strategies for assessing and managing the adverse events of sorafenib and other targeted therapies in the treatment of renal cell and hepatocellular carcinoma: recommendations from a European nursing task group. Eur J Oncol Nurs 16: 172-184

141. Gavrilovic IT, Balagula Y, Rosen AC, Ramaswamy V, Dickler MN, Dunkel IJ et al (2012) Characteristics of oral mucosal events related to bevacizumab treatment. Oncologist 17:274-278

142. Hubiche T, Valenza B, Chevreau C, Fricain JC, Del Giudice P, Sibaud V (2013) Geographic tongue induced by angiogenesis inhibitors. Oncologist 18:e16-e17

143. Rosen AC, Gavrilovic IT, Balagula Y, Ramaswamy V, Dickler $\mathrm{MN}$ et al (2013) Geographic tongue induced by angiogenesis inhibitors: in reply. Oncologist 18:e18

144. Thomas L, Lai SY, Dong W, Feng L, Dadu R, Regone RM et al (2014) Sorafenib in metastatic thyroid cancer: a systematic review. Oncologist 19:251-258

145. Christodoulou C, Pervena A, Klouvas G, Galani E, Falagas ME, Tsakalos $\mathrm{G}$ et al (2009) Combination of bisphosphonates and antiangiogenic factors induces osteonecrosis of the jaw more frequently than bisphosphonates alone. Oncology 76:209-211

146. Ponzetti A, Pinta F, Spadi R, Mecca C, Fanchini L, Zanini M et al. (2016) Jaw osteonecrosis associated with aflibercept, irinotecan and fluorouracil: attention to oral district. Tumori 102(Suppl. 2)

147. Fusco V, Santini D, Armento G, Tonini G, Campisi G (2016) Osteonecrosis of jaw beyond antiresorptive (bone-targeted) agents: new horizons in oncology. Expert Opin Drug Saf 15: 925-935

148. Ruggiero SL, Dodson TB, Fantasia J, Goodday R, Aghaloo T, Mehrotra B et al (2014) American Association of Oral and Maxillofacial Surgeons position paper on medication-related osteonecrosis of the jaw-2014 update. J Oral Maxillofac Surg 72:1938-1956 
149. Gaudin E, Seidel L, Bacevic M, Rompen E, Lambert F (2015) Occurrence and risk indicators of medication-related osteonecrosis of the jaw after dental extraction: a systematic review and metaanalysis. J Clin Periodontol 42:922-932

150. Khan AA, Morrison A, Hanley DA, Felsenberg D, McCauley LK, O'Ryan F et al (2015) Diagnosis and management of osteonecrosis of the jaw: a systematic review and international consensus. J Bone Miner Res 30:3-23

151. Goodday RH (2015) Preventive strategies for patients at risk of medication-related osteonecrosis of the jaw. Oral Maxillofac Surg Clin North Am 27:527-536

152. Rosenbaum SE, Wu S, Newman MA, West DP, Kuzel T, Lacouture ME (2008) Dermatological reactions to the multitargeted tyrosine kinase inhibitor sunitinib. Support Care Cancer 16:557-566

153. Gómez Fernández C, Sendagorta Cudós E, Casado Verrier B, Feito Rodríguez M, Suárez Aguado J, Vidaurrázaga Díaz de Arcaya C (2010) Oral lichenoid eruption associated with imatinib treatment. Eur J Dermatol 20:127-128

154. Amitay-Laish I, Stemmer SM, Lacouture ME (2011) Adverse cutaneous reactions secondary to tyrosine kinase inhibitors including imatinib mesylate, nilotinib, and dasatinib. Dermatol Ther 24: 386-395

155. Zhang JA, Yu JB, Li XH, Zhao L (2015) Oral and cutaneous lichenoid eruption with nail changes due to imatinib treatment in a chinese patient with chronic myeloid leukemia. Ann Dermatol 27:228-229

156. Wahiduzzaman M, Pubalan M (2008) Oral and cutaneous lichenoid reaction with nail changes secondary to imatinib: report of a case and literature review. Dermatol Online J 14:14

157. Pascual JC, Matarredona J, Miralles J, Conesa V, Borras-Blasco J (2006) Oral and cutaneous lichenoid reaction secondary to imatinib: report of two cases. Int J Dermatol 45:1471-1473

158. Ena P, Chiarolini F, Siddi GM, Cossu A (2004) Oral lichenoid eruption secondary to imatinib (Glivec). J Dermatolog Treat 15: 253-255

159. Basso FG, Boer CC, Correa MEP, Torrezan M, Cintra ML, Gallotini de Magalhaes MHC et al (2009) Skin and oral lesions associated to imatinib mesylate therapy. Support Care Cancer 17: 465-468

160. Fitzpatrick SG, Hirsch SA, Gordon SC (2014) The malignant transformation of oral lichen planus and oral lichenoid lesions: a systematic review. J Am Dent Assoc 145:45-56

161. Wong M, Sade S, Gilbert M, Klieb HB (2011) Oral melanosis after tyrosine kinase inhibition with imatinib for chronic myelogenous leukemia: report of a case and review of the literature. Dermatol Online J 17:4

162. Khoo TL, Catalano A, Supple S, Chong L, Yeoh SC, Yeung S et al (2013) Hyperpigmentation of the hard palate associated with imatinib therapy for chronic myeloid leukemia with a genetic variation in the proto-oncogene c-KIT. Leuk Lymphoma 54:186-188

163. Yu YH, Shere Y, Vigneswaran N (2012) Oral and maxillofacial pathology case of the month. Palatal melanosis associated with imatinib mesylate therapy. Tex Dent J 129(764-5):786-788

164. Mattsson U, Halbritter S, Mörner Serikoff E, Christerson L, Warfvinge $G$ (2011) Oral pigmentation in the hard palate associated with imatinib mesylate therapy: a report of three cases. Oral Surg Oral Med Oral Pathol Oral Radiol Endod 111:e12-e16

165. Li CC, Malik SM, Blaeser BF, Dehni WJ, Kabani SP, Boyle N et al (2012) Mucosal pigmentation caused by imatinib: report of three cases. Head Neck Pathol 6:290-295

166. Yuan A, Woo SB (2015) Adverse drug events in the oral cavity. Oral Surg Oral Med Oral Pathol Oral Radiol 119:35-47
167. Balagula Y, Pulitzer MP, Maki RG, Myskowski PL (2011) Pigmentary changes in a patient treated with imatinib. J Drugs Dermatol 10:1062-1066

168. Boutros C, Tarhini A, Routier E, Lambotte O, Ladurie FL, Carbonnel F et al (2016) Safety profiles of anti-CTLA-4 and anti-PD-1 antibodies alone and in combination. Nat Rev Clin Oncol 13:473-486

169. Freeman-Keller M, Kim Y, Cronin H, Richards A, Gibney G, Weber JS (2016) Nivolumab in resected and Unresectable metastatic melanoma: characteristics of immune-related adverse events and association with outcomes. Clin Cancer Res 22:886-894

170. Herbst RS, Baas P, Kim DW, Felip E, Pérez-Gracia JL, Han JY et al (2016) Pembrolizumab versus docetaxel for previously treated, PD-L1-positive, advanced non-small-cell lung cancer (KEYNOTE-010): a randomised controlled trial. Lancet 387: $1540-1550$

171. Hofmann L, Forschner A, Loquai C, Goldinger SM, Zimmer L, Ugurel S et al (2016) Cutaneous, gastrointestinal, hepatic, endocrine, and renal side-effects of anti-PD-1 therapy. Eur J Cancer 60:190-209

172. Schaberg KB, Novoa RA, Wakelee HA, Kim J, Cheung C, Srinivas $S$ et al (2016) Immunohistochemical analysis of lichenoid reactions in patients treated with anti-PD-L1 and anti-PD-1 therapy. J Cutan Pathol 43:339-346

173. Lacouture ME, Duvic M, Hauschild A, Prieto VG, Robert C, Schadendorf D et al (2013) Analysis of dermatologic events in vemurafenib-treated patients with melanoma. Oncologist 18:314-322

174. Boussemart L, Routier E, Mateus C, Opletalova K, Sebille G, Kamsu-Kom N et al (2013) Prospective study of cutaneous sideeffects associated with the BRAF inhibitor vemurafenib: a study of 42 patients. Ann Oncol 24:1691-1697

175. Gençler B, Gönül M (2016) Cutaneous side effects of BRAF inhibitors in advanced melanoma: review of the literature. Dermatol Res Pract 2016:5361569

176. Oberholzer PA, Kee D, Dziunycz P, Sucker A, Kamsukom N, Jones R et al (2012) RAS mutations are associated with the development of cutaneous squamous cell tumors in patients treated with RAF inhibitors. J Clin Oncol 30:316-321

177. Chu EY, Wanat KA, Miller CJ, Amaravadi RK, Fecher LA, Brose MS et al (2012) Diverse cutaneous side effects associated with BRAF inhibitor therapy: a clinicopathologic study. J Am Acad Dermatol 67:1265-1272

178. Mangold AR, Bryce A, Sekulic A (2014) Vemurafenib-associated gingival hyperplasia in patient with metastatic melanoma. J Am Acad Dermatol 71:e205-e206

179. Pileri A, Cricca M, Gandolfi L, Misciali C, Casadei B, Zinzani PL et al (2015) Vemurafenib mucosal side-effect. J Eur Acad Dermatol Venereol 30:1053-1055

180. Flaherty KT, Infante JR, Daud A et al (2012) Combined BRAF and MEK inhibition in melanoma with BRAF V600 mutations. N Engl J Med 367:1694-1703

181. Chang AL, Solomon JA, Hainsworth JD, Goldberg L, McKenna E, Day BM et al (2014) Expanded access study of patients with advanced basal cell carcinoma treated with the Hedgehog pathway inhibitor, vismodegib. J Am Acad Dermatol 70:60-69

182. Epstein JB, Smutzer G, Doty RL (2016) Understanding the impact of taste changes in oncology care. Support Care Cancer 24:1917-1931

183. Sibaud V, Niec RE, Schindler K, Busam KJ, Roché H, Modi S et al (2014) Ado-trastuzumab emtansine-associated telangiectasias in metastatic breast cancer: a case series. Breast Cancer Res Treat 146:451-456

184. Sibaud V, Vigarios E, Combemale P, Lamant L, Lacouture ME, Lacaze JL et al (2015) T-DM1-related telangiectasias: a potential role in secondary bleeding events. Ann Oncol 26:436-437 